\title{
The Early Evolution of Rhynchosaurs
}

\author{
Martín D. Ezcurra ${ }^{1,2 *}$, Felipe Montefeltro ${ }^{2,3}$ and Richard J. Butler ${ }^{2}$ \\ 'Sección Paleontología de Vertebrados, Museo Argentino de Ciencias Naturales "Bernardino Rivadavia," Buenos Aires, \\ Argentina, ${ }^{2}$ School of Geography, Earth and Environmental Sciences, University of Birmingham, Birmingham, UK, \\ ${ }^{3}$ Departamento de Biologia e Zootecnia, FEIS, Universidade Estadual Paulista, Ilha Solteira, Brazil
}

OPEN ACCESS

Edited by:

Michel Laurin,

Muséum National d'Histoire Naturelle,

France

Reviewed by:

Sean P. Modesto,

Cape Breton University, Canada

Fernando Abdala

University of the Witwatersrand, Johannesburg, South Africa

Juan Carlos Cisneros,

Universidade Federal do Piauí, Brazil

*Correspondence:

Martín D. Ezcurra

martindezcurra@yahoo.com.ar

Specialty section:

This article was submitted to

Paleontology,

a section of the journal

Frontiers in Ecology and Evolution

Received: 20 August 2015

Accepted: 30 November 2015

Published: 11 January 2016

Citation:

Ezcurra MD, Montefeltro F and Butler RJ (2016) The Early Evolution of

Rhynchosaurs.

Front. Ecol. Evol. 3:142.

doi: 10.3389/fevo.2015.00142
The rhynchosaurian archosauromorphs are an important and diverse group of fossil tetrapods that first appeared during the Early Triassic and probably became extinct during the early Late Triassic (early Norian). Here, the early evolution of rhynchosaurs during the Early and early Middle Triassic (Induan-Anisian: 252.2-242 Mya) is reviewed based on new anatomical observations and their implications for the taxonomy, phylogenetic relationships and macroevolutionary history of the group. A quantitative phylogenetic analysis recovered a paraphyletic genus Rhynchosaurus, with "Rhynchosaurus" brodiei more closely related to hyperodapedontines than to Rhynchosaurus articeps. Therefore, a new genus is erected, resulting in the new combination Langeronyx brodiei. A body size analysis found two independent increases in size in the evolutionary history of rhynchosaurs, one among stenaulorhynchines and the other in the hyperodapedontine lineage. Maximum likelihood fitting of phenotypic evolution models to body size data found ambiguous results, with body size evolution potentially interpreted as fitting either a non-directional Brownian motion model or a stasis model. A Dispersal-ExtinctionCladogenesis analysis reconstructed the areas that are now South Africa and Europe as the ancestral areas of Rhynchosauria and Rhynchosauridae, respectively. The reconstruction of dispersal events between geographic areas that are broadly separated paleolatitudinally implies that barriers to the dispersal of rhynchosaurs from either side of the paleo-Equator during the Middle Triassic were either absent or permeable.

\section{Keywords: Permo-Triassic, Diapsida, Archosauromorpha, body size, phylogeny, paleobiogeography}

\section{INTRODUCTION}

The Permo-Triassic mass extinction occurred $\sim 252$ million years ago, and produced a dramatic change in the composition of floral and faunal communities (Raup and Sepkoski, 1982; Erwin, 1994; Looy et al., 2001; Benton and Twitchett, 2003; Fröbisch, 2013; Benton and Newell, 2014; Smith and Botha-Brink, 2014). In the case of vertebrates, numerous new lineages first appeared or

Institutional Abbreviations: AM, Albany Museum, Grahamstown, South Africa; BRSUG, University of Bristol, School of Earth Sciences, Bristol, UK; EXEMS, Royal Albert Memorial Museum, Exeter, UK; FZB, Fundação Zoobotânica do Rio Grande do Sul, Porto Alegre, Brazil; GPIT, Paläontologische Sammlung der Universität Tübingen, Tübingen, Germany; ISI, Indian Statistical Institute, Kolkata, India; MACN-Pv, Museo Argentino de Ciencias Naturales "Bernardino Rivadavia," Paleontología de Vertebrados, Buenos Aires, Argentina; NHMUK PV, Natural History Museum, Palaeontology Vertebrates, London, UK; PIMUZ, Paläontologisches Institut und Museum der Universität Zürich, Zurich, Switzerland; PVSJ, Museo de Ciencias Naturales, Universidad de San Juan, San Juan, Argentina; SAM-PK, Iziko South African Museum, Cape Town, South Africa; SIDMM, Sidmouth Museum, Sidmouth, UK; SHYMS, Shropshire Museums, Ludlow, UK; UFRGS, Instituto de Geociências, Universidade Federal do Rio Grande do Sul, Porto Alegre, Brazil; WARMS, Warwickshire Museum, Warwick, UK. 
diversified in the aftermath of this extinction. Many of these lineages replaced clades that flourished during the Paleozoic but vanished or were decimated at the end-Permian mass extinction event (e.g., pareiasaurs, non-mammalian synapsids, such as gorgonopsians and anomodonts). Among the new Triassic clades are the first representatives of several modern vertebrate groups, including teleosts, lissamphibians, eucynodonts, stemtestudinatans, lepidosauromorphs, crocodylomorphs, and stemavialans, including the first non-avian dinosaurs (Bonaparte, 1982; Benton, 1983a; Colbert, 1984; Gaffney, 1986; Arratia, 2001; Bonaparte et al., 2003; Evans, 2003; Marjanovic and Laurin, 2008; Nesbitt, 2011; Jones et al., 2013; Ezcurra et al., 2014; Schoch and Sues, 2015).

The Triassic also witnessed the evolution of numerous amniote groups that occur only within this time interval and which became extinct at or before the end-Triassic mass extinction event (e.g., traversodontids, doswelliids, tanystropheids, aetosaurs, phytosaurs; Abdala and Ribeiro, 2010; Liu and Olsen, 2010; Desojo et al., 2013; Stocker and Butler, 2013; Sues et al., 2013; Pritchard et al., 2015). Although restricted to the Triassic, these groups achieved high morphological diversity and taxonomic richness, and some of them become key ecological components of their communities (Benton, 1983a; Sues and Fraser, 2013). The rhynchosaurian archosauromorphs were one of the most successful of these groups, and radiated widely in continental ecosystems (Romer, 1963; Chatterjee, 1980; Benton, 1990). Most rhynchosaurs were bulky, herbivorous and quadrupedal animals, often considered as superficially pig-like in appearance, with a transversely broad skull and a highly specialized dentition (Chatterjee, 1980; Benton, 1984, 1990; Langer and Schultz, 2000; Hone and Benton, 2008; Figures 1B,C). The rhynchosaur genus Hyperodapedon is the most commonly found tetrapod within the oldest dinosaurbearing assemblages (e.g., the Ischigualasto, Santa María 2, lower Maleri and Pebbly Arkose formations), and, as a result, has been broadly used for global biostratigraphic correlations (Langer, 2005; Lucas, 2010; Martínez et al., 2011).

Because of the importance of rhynchosaurs during the beginning of the Mesozoic, the early evolution of the group during the Early and early Middle Triassic (Induan-Anisian: 252.2-242 Mya) is reviewed here. New anatomical observations are presented, and their implications for the taxonomy, phylogenetic relationships and macroevolutionary history of the group are analyzed and discussed.

\section{MATERIALS AND METHODS}

\section{Phylogenetic Analysis}

New anatomical observations presented here for several early rhynchosaur species provide an impetus to revisit the phylogenetic relationships among basal members of the clade. This analysis used a modified version of the data matrix of Butler et al. (2015), the taxonomic sample of which focuses on rhynchosaurs outside of the species-rich genus Hyperodapedon. We modified several scorings for Rhynchosaurus articeps, "Rhynchosaurus" brodiei, Stenaulorhynchus stockleyi, and
Fodonyx spenceri based on new, first-hand observations of specimens. We added three characters from previously published phylogenetic analyses relevant to the basal relationships of Rhynchosauria (Dilkes, 1998; Ezcurra et al., 2014, 2015) and we modified the formulation of two characters from the original character list of Butler et al. (2015: characters 63 and 84; see Supplementary Material). We also expanded the taxonomic sampling of the analysis by adding the oldest known rhynchosaur, Noteosuchus colletti (Watson, 1912; Carroll, 1976; Dilkes, 1998; Ezcurra et al., 2014). Scoring of taxa was based primarily on first-hand examination of specimens, with the exception of Isalorhynchus genovefae, which was scored using Langer et al. (2000a) and Whatley (2005).

The final matrix (15 taxa and 96 characters) was analyzed using TNT version 1.1 (Goloboff et al., 2008) using the implicit enumeration algorithm. Multistate characters 63,70, 73, and 75 were treated as additive because they represent nested sets of homologies. Zero branch length nodes were collapsed following the search (Coddington and Scharff, 1994). Absolute and GC bootstrap frequencies were calculated after 10,000 pseudoreplicates. GC bootstrap frequencies are the difference between the frequencies with which the original group and the most frequent contradictory group are recovered in the pseudoreplicates (Goloboff et al., 2003). Templeton tests were conducted in PAUP* 4.0 (Swofford, 1998).

\section{Body Size Analysis}

The phylogenetic reconstruction of early rhynchosaurs obtained here was merged with the phylogenetic tree of the bestknown species of the genus Hyperodapedon recovered by Langer and Schultz (2000) (i.e., Hyperodapedon mariensis, Hyperodapedon sanjuanensis, Hyperodapedon gordoni, and Hyperodapedon huxleyi) to form an informal supertree for Rhynchosauria. We merged the trees manually because their topologies are consistent with each other where their taxonomic content overlaps ( $R$. articeps, S. stockleyi, F. spenceri, Teyumbaita sulcognathus). The early rhynchosaur $N$. colletti was excluded a priori before merging both trees because it lacks cranial remains and it is not possible to estimate its skull length confidently.

Two analyses were conducted based upon this supertree to explore the evolution of body size across Anisian-early Norian rhynchosaur history ( $\sim 20$ million years). In one analysis, we optimized skull length (i.e., length from the anterior tip of the premaxilla to posterior margin of the distal end of the quadrate) as a proxy of body size and a continuous character, employing maximum parsimony and using the algorithm implemented by TNT version 1.1 to handle continuous data as such (Goloboff et al., 2006). In the other analysis, we tested the fit of different models of evolution to the observed changes in skull length in rhynchosaurs. The following five evolutionary models were fitted to the time-calibrated tree: Brownian motion (equivalent to an unbiased random walk, which assumes a correlation structure among traits that is proportional to shared ancestry or branch lengths among sister taxa; Felsenstein, 1973; Harmon et al., 2008), Ornstein-Uhlenbeck (OU: fits a model of stabilizing selection, whereby traits evolve via a random walk with a central tendency; Butler and King, 2004), early burst (fits a model where the rate 


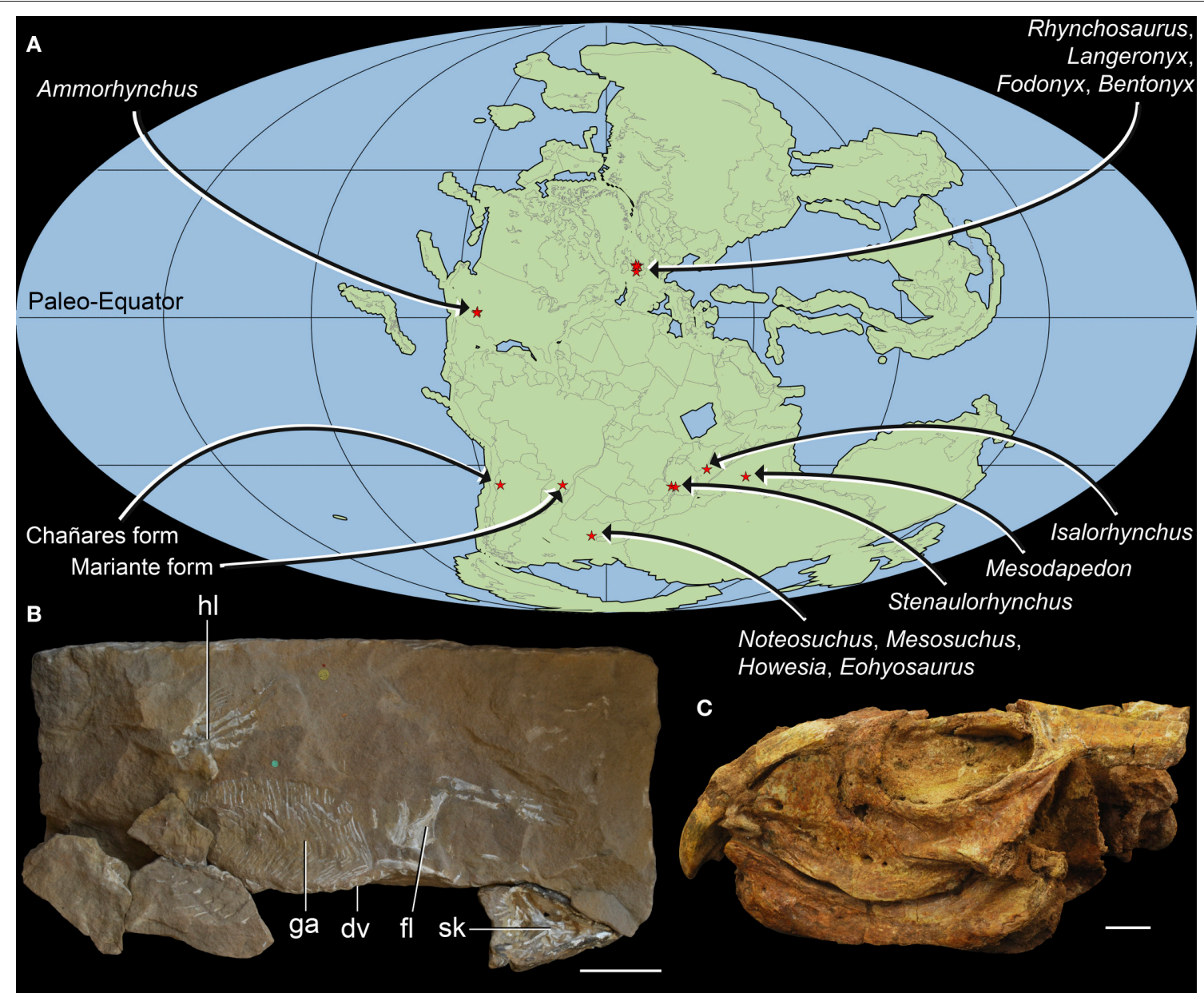

FIGURE 1 | Geographic distribution and overall morphology of Early-Middle Triassic rhynchosaurs. Paleomap showing geographical distribution (A) and early rhynchosaurid morphology exemplified by (B) a partial skeleton of Rhynchosaurus articeps (NHMUK PV R1237, R1238) and (C) the fairly complete skull of Bentonyx sidensis (BRSUG 27200, holotype). Abbreviations: dv, dorsal vertebrae; fl, forelimb; ga, gastralia; hl, hindlimb; sk, skull. Scale bars equal to 5 cm in (B) and $1 \mathrm{~cm}$ in (C). Map (A) generated using Fossilworks tools created by Alroy (2013) using a map for 240 million years ago created by Scotese (2001) and data from the Paleobiology Database (www.paleobiodb.org).

of evolution increases or decreases exponentially through time; Harmon et al., 2010), BM + trend (diffusion model with linear trend in rates through time), and stasis (= "white" model of Geiger; non-phylogenetic model that assumes a single normal distribution with no covariance structure among species). A punctuational model (= kappa, speciational; assumes that trait divergence among taxa is related to the number of speciation events; Pagel, 1999) was not included as it is very likely that the rhynchosaur fossil record presents only an incomplete taxonomic sampling of total rhynchosaur diversity. The five models were tested in the software environment $\mathrm{R}$ ( $\mathrm{R}$ Development Core Team, 2013), using the fitContinuous function of the package Geiger, which uses maximum likelihood as the optimization criterion (Harmon et al., 2008). Corrected Akaike's Information Criterion (AICc) was used to compare the fit of the different models, and the percentage of data explained for each model was calculated with the akaike.wts function of the package paleoTS for $\mathrm{R}$ (Hunt, 2006). We realized during the analyses that different replicates of fitting of the same data set produced different AICcs values for the OU model. As a result, we conducted 100 replicates for each model, and present the mean AICc value.

The rhynchosaur tree was calibrated separately to the mean and lower and upper bounds, respectively, of the chronostratigraphic uncertainty of the sampled species using the date.phylo function of Graeme Lloyd (http://www.graemetlloyd. com/methdpf.html) for $\mathrm{R}$, and analyses were run multiple times using these alternative calibrations. Root length was set as 0.1 million years and the chosen time calibration method shared time equally between branches (Brusatte et al., 2008). Hy. mariensis was found in a trichotomy with Hy. sanjuanensis and Hy. gordoni $+H y$. huxleyi by Langer and Schultz (2000), but the model-fitting analyses require a fully dichotomous tree. As a result, Hy. mariensis was pruned a priori because it is slightly smaller than the other taxa present in the polytomy (i.e., Hy. sanjuanensis) and 
may not therefore represent the maximum body size present in the species. Skull lengths for the different rhynchosaur species were obtained from published sources and personal measurements/estimations, and the maximum recorded measurements were used for each species (see Supplementary Material). It was not possible to use mean body sizes of adult individuals because the skeletochronology of rhynchosaurs is still not well-understood.

\section{Paleobiogeographic Analysis}

We used the same informal supertree as in the body size analysis, but did not exclude $N$. colletti or Hy. mariensis. $N$. colletti can occupy three different but equally parsimonious phylogenetic positions (see results of the phylogenetic analysis) and two possible alternative positions for $\mathrm{Hy}$. mariensis were recovered by Langer and Schultz (2000). As the paleogeographic analyses required a fully dichotomous tree, we generated six alternative topologies for the informal supertree, each of which was time calibrated using the mean of the chronostratigraphic uncertainty of each sampled species and the same protocol as in the body size analysis. To explore the early paleobiogeographic history of rhynchosaurs we used a Dispersal-Extinction-Cladogenesis (DEC) analysis to reconstruct the ancestral ranges of the sampled cladogenetic events (Ree et al., 2005; Ree and Smith, 2008). This analysis infers the optimal ancestral ranges and biogeographical events based on a time calibrated phylogenetic tree and uses a maximum likelihood approach that is sensitive to branch lengthes (maximum time from the origin of each node). The distribution of Induan-Anisian rhynchosaurs was divided into four geographic areas based on the geographic proximity of the localities during the Triassic, namely South Africa, South America, Europe, and Tanzania-India-Madagascar (see Supplementary Material). The analysis was conducted for each of the six topologies and finally combined into a single result using the "Combine Results" function of RASP 3.2 (Yu et al., 2015). The combined result was plotted on the time calibrated strict consensus of the six analyzed trees.

\section{RESULTS}

\section{Induan}

Pre-Triassic rhynchosaurs are unknown, although the Permian origin of the clade is suggested by phylogenetic topologies, with a ghost lineage extending across the Permo-Triassic boundary, into the late Permian (Ezcurra et al., 2014). The Early Triassic rhynchosaur record is restricted to a single, articulated partial postcranium that represents the holotype (AM 3591) of N. colletti (=Eosuchus colletti; Watson, 1912; Table 1).

\section{Noteosuchus colletti}

This species is the oldest known rhynchosaur and was collected at the base of the Lystrosaurus Assemblage Zone (AZ; Induan), near Grass Ridge (Eastern Cape Province), in the Karoo Basin of South Africa (Watson, 1912; Broom, 1925; Carroll, 1976; Dilkes, 1998; Ezcurra et al., 2014; Figures 2A-E,G). Watson (1912, 1917) originally identified N. colletti as an "eosuchian" (a group of reptiles currently considered to be polyphyletic, but previously considered to include the ancestors of the main diapsid lineages) and Broom (1925) interpreted it as a form ancestral to "gnathodonts," rhynchocephalians, "pelycosimians," and phytosaurs. Nopsca (1928) classified N. colletti as an early rhynchosaur within the family Howesiidae, but subsequent authors returned to the concept that it was an eosuchian (e.g., Huene, 1939; Romer, 1956, 1966; Kuhn, 1969). Carroll (1976) revised the anatomy of $N$. colletti and identified it as the oldest known rhynchosaur. More recently, Dilkes (1998) suggested that $N$. colletti might be potentially a junior synonym of the stratigraphically younger rhynchosaur Mesosuchus browni because the two are consistent in morphology and share two possibly diagnostic characters (a median ventral groove on the centra of the first two caudal vertebrae, a flattened first distal tarsal). N. colletti was ignored in most other recent discussions of rhynchosaur evolution (e.g., Benton, 1983b, 1990; Wilkinson and Benton, 1995; Hone and Benton, 2008; Montefeltro et al., 2013; Mukherjee and Ray, 2014).

TABLE 1 | List of known Induan-Anisian rhynchosaur nominal species and their temporal and geographic occurrence ordered by chronostratigraphic age.

\begin{tabular}{|c|c|c|c|}
\hline Species & Occurrence & Age & Material \\
\hline Noteosuchus colletti (Watson, 1912) & Katberg Formation, South Africa & Induan & Single partial postcranium \\
\hline Mesosuchus browni Watson, 1912 & Burgersdorp Formation, South Africa & Early Anisian & $\begin{array}{l}\text { Four partial skeletons, including a fairly } \\
\text { complete skull }\end{array}$ \\
\hline Howesia browni Broom, 1905 & Burgersdorp Formation, South Africa & Early Anisian & $\begin{array}{l}\text { Two partial skulls, one including atlas-axis, } \\
\text { and a partial postcranium }\end{array}$ \\
\hline Eohyosaurus wolvaardti Butler et al., 2015 & Burgersdorp Formation, South Africa & Early Anisian & $\begin{array}{l}\text { Single partial skull associated with two limb } \\
\text { bone fragments }\end{array}$ \\
\hline $\begin{array}{l}\text { Ammorhynchus navajoi Nesbitt and } \\
\text { Whatley, } 2004\end{array}$ & Holbrook Member, Moenkopi Formation, USA & Early Anisian & $\begin{array}{l}\text { Three partial maxillae and a fragment of } \\
\text { dentary }\end{array}$ \\
\hline Bentonyx sidensis Langer et al., 2010 & Otter Sandstone Formation, UK & Late Anisian & Fairly complete skull \\
\hline Fodonyx spenceri (Benton, 1990) & Otter Sandstone Formation, UK & Late Anisian & Single partial skull \\
\hline Stenaulorhynchus stockleyi Haughton, 1932 & Lifua Member, Manda beds, Tanzania & Late Anisian & Numerous skeletons and isolated bones \\
\hline Mesodapedon kuttyi Chatterjee, 1980 & Yerrapalli Formation, India & Anisian & A partial maxilla and two dentaries \\
\hline Rhynchosaurus articeps Owen, 1842a & Tarporley Siltstone Formation, UK & Anisian & Multiple partial skeletons \\
\hline Langeronyx brodiei (Benton, 1990) & Bromsgrove Sandstone Formation, UK & Anisian & Single partial skull \\
\hline
\end{tabular}




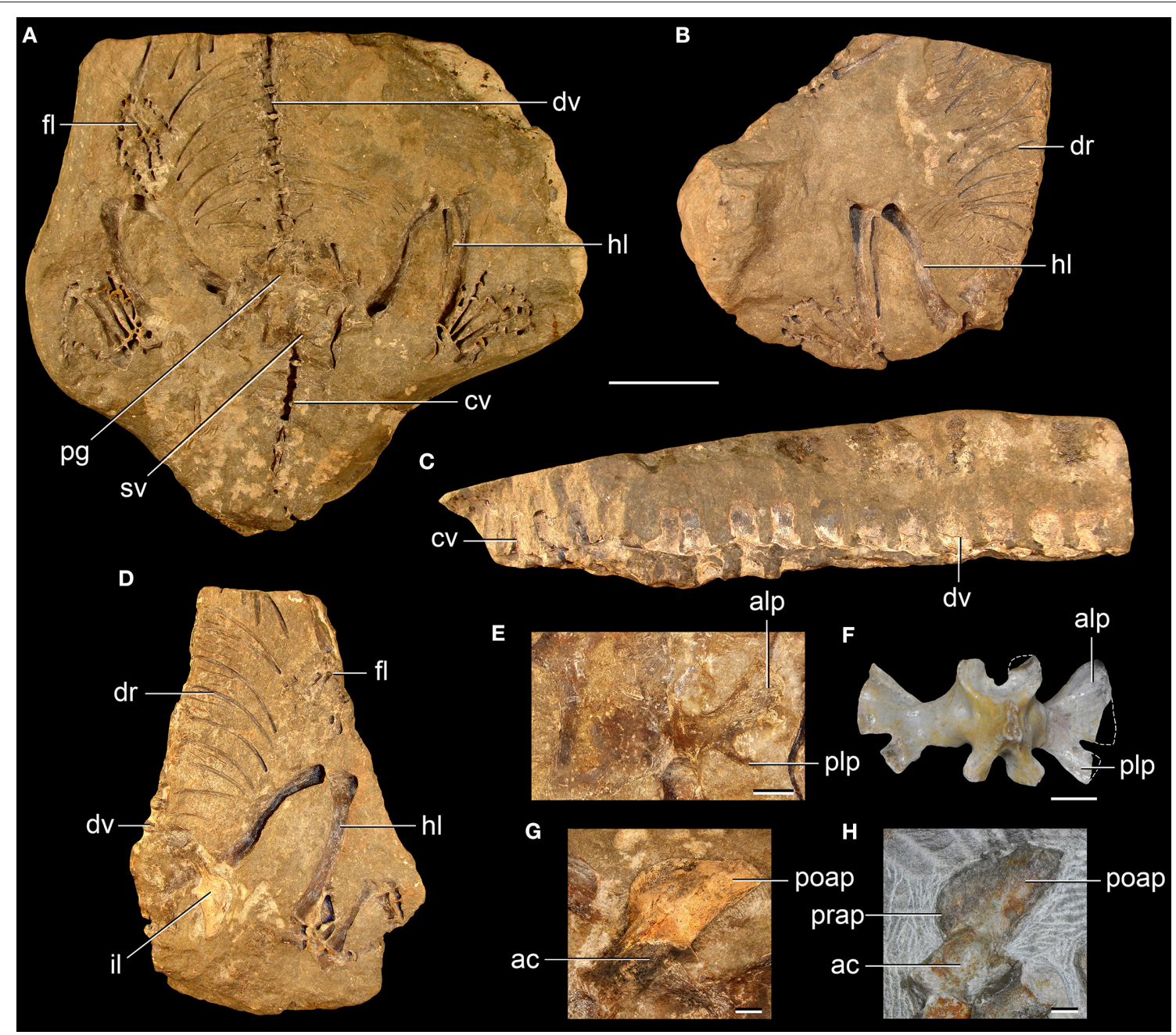

FIGURE 2 | Noteosuchus colletti from the Induan of South Africa. N. colletti (A-E,G) compared with selected bones of Mesosuchus browni (F, H) from the early Anisian of South Africa. Lower block (A), upper right block (B), and upper left block (C,D), close-up of right second sacral rib in either dorsal or ventral view (E), and close-up of left ilium in lateral view (G) of N. colletti (AM 3591, holotype); and second sacral vertebra and ribs in dorsal view (SAM-PK-6046) (F) and left ilium in lateral view (SAM-PK-7416) (H) of M. browni. Abbreviations: ac, acetabulum; alp, anterolateral process; cv, caudal vertebrae; dr, dorsal ribs; dv, dorsal vertebrae; fl, forelimb; hl hindlimb; il, ilium; poap, postacetabular process; prap, preacetabular process; pg, pelvic girdle; plp, posterolateral process; sv, sacral vertebrae. Scale bars equal $5 \mathrm{~cm}$ in (A-D) and $5 \mathrm{~mm}$ in (E-H).

Ezcurra et al. (2014) scored N. colletti and M. browni as independent terminals in their phylogenetic analysis because the temporal gap between the two species apparently spans most of the Early Triassic (ca. 5 million years) and, as a result, the former species could potentially shed light on the minimal divergence time of Rhynchosauria. These authors recovered $N$. colletti and M. browni within Rhynchosauria, in a trichotomy with Howesia browni. This result and differences in scorings between $N$. colletti and $M$. browni support the idea that the former represents a distinct species of early rhynchosaur (Ezcurra et al., 2014). A single synapomorphy supported the position of $N$. colletti within Rhynchosauria in this analysis: ratio of lengths of metatarsals I and IV equal to or lower than 0.32 .

Carroll (1976) redescribed the holotype of $N$. colletti after removing mechanically most of the bones and producing latex casts from the resultant molds. Carroll (1976) increased considerably the anatomical knowledge of the species and made comparisons with other rhynchosaurs and the proterosuchid archosauriform Proterosuchus. Our first hand re-examination of the specimen was partially limited because no casts of the molds were available. However, some reinterpretations and new anatomical data are added here that help distinguish this species from $M$. browni and that may be useful for future phylogenetic analyses of early archosauromorphs.

The second sacral rib of $N$. colletti bifurcates distally (Carroll, 1976), with a thin and distally tapering posterolateral process of the rib in ventral view (Figure 2E: plp), as occurs in some tanystropheids (e.g., Macrocnemus bessanii: PIMUZ T2472), the rhynchosaurids S. stockleyi (Huene, 1938), $R$. articeps (SHYMS 5) and I. genovefae (Whatley, 2005), and 
the archosauriform Proterosuchus alexanderi (NMQR 1484). By contrast, the non-archosauriform archosauromorphs Pamelaria dolichotrachela (ISI R333/1; Ezcurra et al., 2015) and Prolacerta broomi (Gow, 1975), the early rhynchosaurs M. browni (SAMPK-6046, Dilkes, 1998) and H. browni (SAM-PK-5886) also possess a bifurcated second sacral rib, but the posterolateral process of the rib is broad and squared-off in ventral view (Figure 2F: plp). The second sacral rib of most Late Triassic rhynchosaurs does not bifurcate distally (Chatterjee, 1974; Benton, 1983b; Dilkes, 1998). The heights of the neural spines of the anterior caudal vertebrae of $N$. colletti are around 2.1 times the anteroposterior lengths of their bases, contrasting with the proportionally higher neural spines of the anterior caudals of M. browni (SAM-PK-6046, second to fourth caudal: ratio equals 3.0-3.5) and $H$. browni (SAM-PK-5886: 2.6-3.0). The preacetabular process of the ilium is absent and the postacetabular process is mainly posteriorly directed in lateral view in $N$. colletti (Figure 2G). By contrast, the preacetabular process of M. browni (SAM-PK-7416) and H. browni (SAMPK-5886) is distinctly developed, but short and rounded, and the postacetabular process is posterodorsally directed (Figure 2H).

We agree here with Dilkes (1998) in the interpretation of a median longitudinal groove in the first two caudal centra as a feature shared between $N$. colletti and M. browni, but absent in other rhynchosaurs, Pamelaria dolichotrachela (ISI R316/1), Trilophosaurus buettneri (Spielmann et al., 2008), Prolacerta broomi, and basal archosauriforms (e.g., Proterosuchus alexanderi: NMQR 1484). The second possible diagnostic feature suggested by Dilkes (1998) to be shared between N. colletti and M. browni is a proximodistally flattened first distal tarsal. However, the first distal tarsal of $N$. colletti is sub-quadrangular in dorsal or lateral view (AM 3591; Carroll, 1976: Figure 6C), resembling the condition in other basal archosauromorphs (e.g., H. browni: Dilkes, 1995). Therefore, the anatomical characters discussed above show several differences in the sacral and caudal vertebrae and pelvic girdle that support the taxonomic distinction between $N$. colletti and M. browni, but there is also evidence suggesting that these species could be closely related to each other.

\section{Early Anisian}

Rhynchosaurs of probable earliest Middle Triassic (early Anisian) age are currently known from the Karoo Basin of South Africa and the Holbrook Member of the Moenkopi Formation of the USA (Figure 1A; Table 1). Rhynchosaur remains are more abundant (although still scarce) in the early Anisian record than in the Induan-Olenekian. Eight specimens from the Karoo Basin are currently assigned to Rhynchosauria (Dilkes, 1995, 1998; Butler et al., 2015), although additional undescribed specimens of $M$. browni are probably present among material collected from its type locality (RJB, pers. obs.). These Karoo specimens represent the basis for three species: M. browni, H. browni, and Eohyosaurus wolvaardti (Broom, 1905; Watson, 1912; Dilkes, 1995, 1998; Butler et al., 2015), which provide the best information currently available on the earliest phase of evolution of the group. The North American Ammorhynchus navajoi represents another early Anisian rhynchosaur species (Nesbitt and Whatley, 2004). A potential early Anisian rhynchosaur from Europe is Eifelosaurus triadicus from the Upper Buntsandstein of Germany (Jaekel, 1904). This species has been occasionally identified as a rhynchosaur (e.g., Huene, 1929), but is based upon a single incomplete postcranial skeleton, and no further studies have yet been conducted to determine its affinities. However, some undescribed rhynchosaur material may be present in equivalent stratigraphic levels in Germany (R. Schoch, pers. comm.).

The British species R. articeps and "Rhynchosaurus" brodiei, and the Indian species Mesodapedon kuttyi, are also dated as broadly Anisian in age. As a result, they could be coeval with the early Anisian species from South Africa and the USA, or they could be somewhat younger (see below).

\section{Mesosuchus browni, Howesia browni, and Eohyosaurus wolvaardti}

The Burgersdorp Formation of the Karoo Basin of South Africa preserves a rich late Olenekian-Anisian tetrapod fossil record that forms the basis for the Cynognathus Assemblage Zone (Hancox, 2000; Rubidge, 2005). This has been subdivided into three biochronological assemblages known as Cynognathus subzones A to C (Hancox et al., 1995). The Burgersdorp Formation has been worked by paleontologists for around 150 years (although much less intensively in Cynognathus subzones A and C, which have been studied only relatively recently), but the eight currently known rhynchosaur specimens are restricted to Cynognathus subzone B, currently hypothesized to be early Anisian in age on the basis of vertebrate biostratigraphic correlations (Hancox, 2000).

H. browni was the first rhynchosaur described from the Burgersdorp Formation (Broom, 1905) and its affinities with Middle and Late Triassic rhynchosaurids were recognized at an early stage on the basis of similarities in the dentition (Broom, 1906). Watson (1912) erected the new genus and species $M$. browni, and Broom (1913) identified its close relationships with $H$. browni and rhynchosaurids, an interpretation that has been supported by subsequent authors (e.g., Haughton, 1924; Nopsca, 1928; Huene, 1956; Chatterjee, 1969, 1974, 1980; Carroll, 1976). Dilkes $(1995,1998)$ redescribed in detail both South African species and provided strong evidence that M. browni and $H$. browni are successive outgroups of Rhynchosaurus and the remaining Middle and Late Triassic rhynchosaurs, respectively. More recently, Butler et al. (2015) named a third species of rhynchosaur, E. wolvaardti, from the Burgersdorp Formation. This species is based on a single, partial skull and two partial limb bones (one preserved as a natural mold) and was recovered as the sister taxon of Rhynchosauridae (i.e., R. articeps and other Middle and Late Triassic rhynchosaurs). The anatomy of the early rhynchosaurs from the Burgersdorp Formation is not revisited here because no further information can be added at this stage to the detailed redescriptions of $M$. browni and $H$. browni recently conducted by Dilkes $(1995,1998)$ and the recent description of E. wolvaardti by Butler et al. (2015). However, computed tomographic study of the endocranial cavities of $M$. browni and E. wolvaardti is currently ongoing (Sobral et al. in prep.). 


\section{Ammorhynchus navajoi}

The oldest rhynchosaur remains known from North America were collected in the Holbrook Member of the Moenkopi Formation of the southwestern United States (Arizona) and were interpreted as belonging to a distinct genus and species by Nesbitt and Whatley (2004): A. navajoi. The Holbrook Member of the Moenkopi Formation is considered early Anisian in age based upon magnetostratigraphy and vertebrate biostratigraphy (Lucas and Schoch, 2002). A. navajoi is known from a nearly complete left maxilla (holotype) as well as two partial maxillae and a dentary (referred specimens), and is a rare component in the Moenkopi vertebrate assemblage. This species possesses several rows of closely packed lingual maxillary teeth, resembling the condition in S. stockleyi (e.g., NHMUK PV R9272, R9280, R9281), and M. kuttyi (Chatterjee, 1980).

\section{Late Anisian}

The late Anisian rhynchosaur record is composed of multiple specimens collected in the Otter Sandstone Formation of southwest England and the Manda beds of Tanzania (Figure 1A; Table 1). Two nominal species are currently recognized in the Otter Sandstone (Bentonyx sidensis and F. spenceri) and one from the Manda beds (S. stockleyi) (Haughton, 1932; Huene, 1938; Benton, 1990; Hone and Benton, 2008; Langer et al., 2010). Rhynchosaurs are, together with temnospondyls, the most abundant vertebrates of the Otter Sandstone fossil assemblage, with more than 20 specimens accessioned into public collections, and many additional specimens present in private collections (MDE and RJB pers. obs. in SIDMM, EXEMS and NHMUK PV). S. stockleyi is the numerically dominant vertebrate in the Manda beds, and Benton (1983a) estimated that it represents around $45 \%$ of the total of sampled specimens. As a result, rhynchosaurs are considerably more numerically abundant in absolute numbers and relative proportions in late Anisian units than in the Induan-early Anisian beds of South Africa and the USA. No rhynchosaur specimen has been collected so far from the late Anisian Cynognathus Assemblage Zone, Subzone C, of South Africa or from approximately coeval beds of South America, Antarctica, and Asia (excluding India; Rubidge, 2005; Lucas, 2010), although most of these areas are very poorly sampled for this time interval.

\section{Bentonyx sidensis and Fodonyx spenceri}

Rhynchosaur specimens from the Otter Sandstone, on the southwest coast of England (Devon), have been known since the second half of the nineteenth century and informally referred as the "Devon rhynchosaur" (Benton, 1990). The vertebrate fossilbearing horizons in the Otter Sandstone are identified as late Anisian in age on the basis of magnetostratigraphy (Benton, 2011). Benton (1990) interpreted the "Devon rhynchosaur" as the new species "Rhynchosaurus" spenceri and designated as holotype an isolated, partial skull (EXEMS 60/1985.292; Figure 3B). Benton et al. (1993) referred a partial postcranium to this species (EXEMS 79/1992). Wilkinson and Benton (1995) found "Rhynchosaurus" spenceri as more closely related to hyperodapedontines than to $R$. articeps in a cladistic analysis, and suggested that the former species should be transferred to a new genus. The same phylogenetic position for "Rhynchosaurus" spenceri was also recovered by Langer and Schultz (2000), but they did not conduct any taxonomic modification. Hone and Benton (2008) agreed with these results and erected the new genus Fodonyx for "Rhynchosaurus" spenceri, thereby creating the new combination F. spenceri. In their paper, Hone and Benton (2008) described a new, fairly complete skull from the Otter Sandstone (BRSUG 27200) and referred it to F. spenceri.

Langer et al. (2010) revisited the taxonomy of the Devon rhynchosaur specimens and found strong evidence in support of a taxonomic distinction between the holotype of F. spenceri (EXEMS 60/1985.292) and the more recently described skull (BRSUG 27200; Figure 1C). The latter specimen was interpreted as the holotype of the new genus and species, B. sidensis, and, because of the lack of overlapping bones, the postcranium (EXEMS 79/1992) described by Benton et al. (1993) was reinterpreted as an indeterminate rhynchosaurid (Langer et al., 2010). As a result, B. sidensis and F. spenceri are currently restricted to their holotypes. $B$. sidensis was described in detail by Hone and Benton (2008) and complemented by Langer et al. (2010), whereas F. spenceri was described in detail by Benton (1990), with further comments made by Hone and Benton (2008) and Langer et al. (2010). We mostly agree with previous interpretations after first hand restudy of the holotypes of both species, and only a few comments on the cheek region of $F$. spenceri are made here.

The jugal of F. spenceri is strongly laterally elevated along the ventral border of the orbit, forming a sharp edge (Figure 3B: rbo), resembling the condition in $R$. articeps (NHMUK PV R1236, SHYMS 1), "Rhynchosaurus" brodiei (WARMS G6097/1), S. stockleyi (NHMUK PV R2270, R36840), and B. sidensis (BRSUG 27200; Figure 3: rbo). The orientation of the orbit in F. spenceri is difficult to determine because of the fragmentary condition of the holotype specimen. However, the level of the ventral margin of the orbit with respect to the upper temporal bar indicates that the orbit was mainly laterally facing (e.g., Benton, 1990: Figure 28a), as occurs in other Middle Triassic rhynchosaurs (e.g., R. articeps: NHMUK PV R1236, SHYMS 1, "Rhynchosaurus" brodiei: WARMS G6097/1, B. sidensis: BRSUG 27200). By contrast, the upper temporal bar is placed only slightly above the level of the ventral margin of the orbit in Teyumbaita and species of Hyperodapedon and, as a result, the orbit is mainly dorsally facing (Langer and Schultz, 2000; Montefeltro et al., 2010).

The posterior process of the right jugal of the holotype of F. spenceri is complete, and is posterolaterally directed, short and subtriangular in lateral view (EXEMS 60/1985.292; Figure 3B: ppj). The distal end of this process possesses a series of longitudinal striations on the lateral surface, but it lacks an articular facet on either the medial or lateral surface. The lack of articular facets and the proportionally short length of the posterior process indicate that the jugal failed to contact the quadratojugal, and that the lower temporal bar was incomplete, resembling the condition in E. wolvaardti (Butler et al., 2015) and $R$. articeps (NHMUK PV R1236, SHYMS 1, 3). In addition, an isolated, very well-preserved right jugal from the Otter Sandstone (Figures 3D,E; EXEMS 60/1985.20) possesses a 


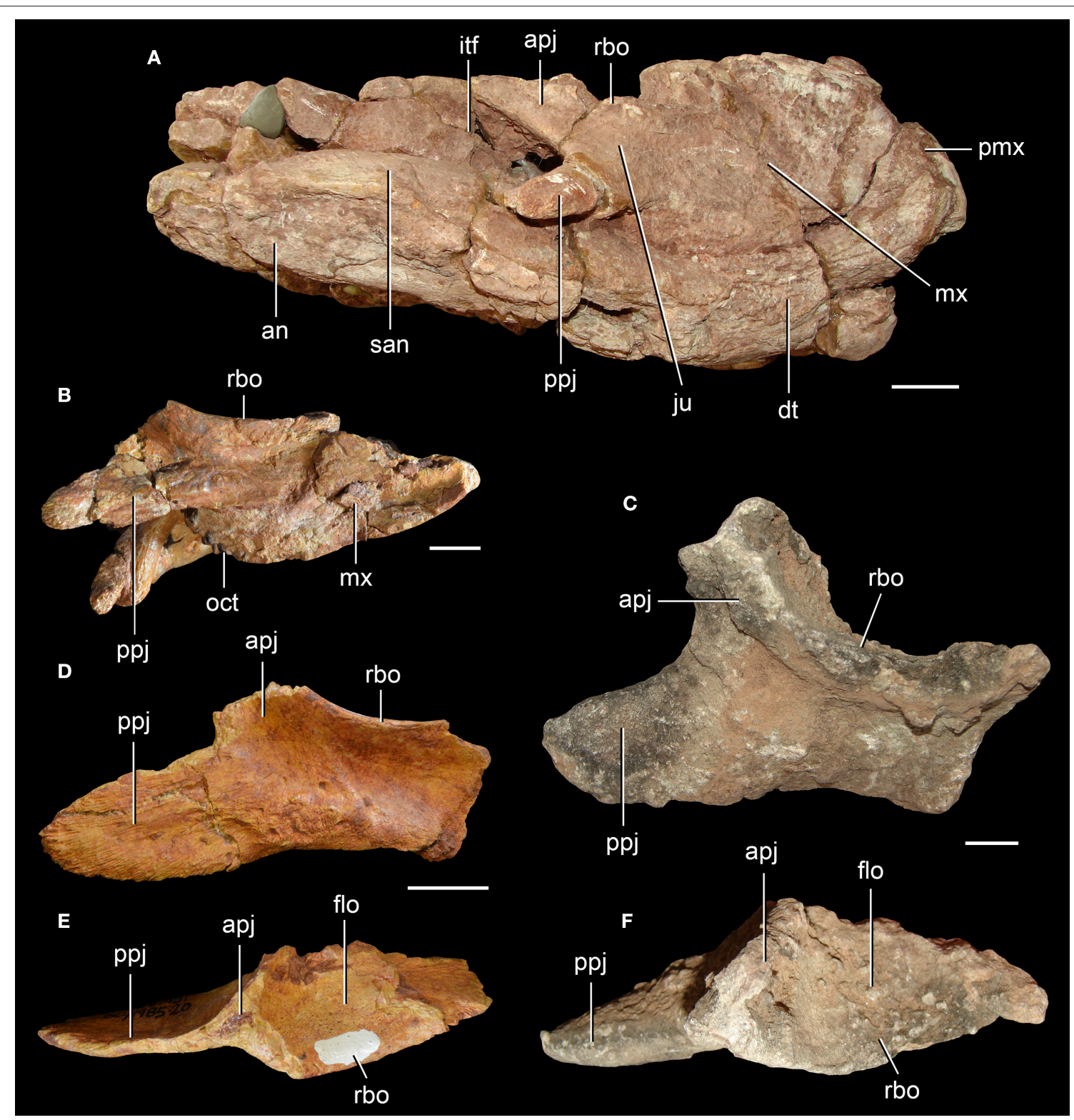

FIGURE 3 | Incomplete lower temporal bar in the Middle Triassic rhynchosaurs. S. stockleyi (A: NHMUK PV R2270; C, F: NHMUK PV R36840) (A,C,F) and Fodonyx spenceri (EXEMS 60/1985.292, holotype) (B), and an indeterminate rhynchosaurid from the Otter Sandstone (EXEMS 60/1985.20) (D,E). Partial skulls in right lateral view (A,B) and isolated right jugal in lateral (C,D), and dorsal (E,F) views. Abbreviations: an, angular; apj, ascending process of the jugal; dt, dentary; flo, floor of the orbit; itf, infratemporal fenestra; ju, jugal; mx, maxilla; oct, occlusal teeth; pmx, premaxilla; ppj, posterior process of the jugal; rbo, raised border of the orbit; san, surangular. Scale bars equal $2 \mathrm{~cm}$ in (A) and $1 \mathrm{~cm}$ in (B-F).

morphology consistent with those of B. sidensis (BRSUG 27200) and F. spenceri (EXEMS 60/1985.292). In this specimen the posterior process is short and lacks facets for articulation with the quadratojugal. Therefore, this specimen provides further evidence for a rhynchosaur species with an incomplete lower temporal bar in the Otter Sandstone.

\section{Stenaulorhynchus stockleyi}

The Lifua Member of the Manda beds of Tanzania (identified as late Anisian on the basis of vertebrate biostratigraphy: Nesbitt et al., 2010) has yielded multiple specimens of the mediumsized rhynchosaurid S. stockleyi (Haughton, 1932; Huene, 1938). This species was originally named by Haughton (1932) based on an isolated proximal half of right humerus (SAM-PK10645) that was designated as holotype, as well as referred humeri, femora, vertebrae, and left and right maxillae. Haughton (1932) recognized that the limb bones of S. stockleyi closely resembled those of Late Triassic rhynchosaurs from Brazil. In the same contribution, Haughton (1932) erected a second species, Stenaulorhynchus major, based on the distal half of a left 
humerus. Subsequently, Huene (1939) considered the holotype of Stenaulorhynchus major [SAM-PK-10653(a)] indistinguishable from the humerus of the suchian archosaur Stagonosuchus nyassicus from the same locality and horizon, and he referred the former bone to the latter species. More recently, Lautenschlager and Desojo (2011) reinterpreted the maxillae and vertebrae of the original referred material of $S$. stockleyi as belonging to an archosaur rather than a rhynchosaur. The reinterpretation of the maxilla [SAM-PK-10651(d)] as belonging to an archosaur is supported here, but in the case of the vertebrae (SAM-PK10652), we could not find features that are inconsistent with those present in rhynchosaurs. Conversely, the vertebrae lack archosaur synapomorphies based on the figures and description of Haughton (1932: Figure 16) and are considered here as belonging to an indeterminate archosauromorph.

Huene (1938) considerably improved the anatomical knowledge of $S$. stockleyi by describing multiple referred specimens, including bones from all anatomical regions of the skeleton. This contribution is the most comprehensive description of the anatomy of the species currently available. Huene (1938) noted that no jugal was completely preserved in the available specimens, but considered it likely that it extended along the entire ventral border of the infratemporal fenestra and formed a contact with the quadratojugal. The most complete and best-preserved skull of S. stockleyi (GPIT/RE/7192) possesses both posterior processes of the jugals reconstructed with plaster as if the lower temporal bar was complete. As a result, a firsthand analysis of this specimen cannot successfully determine the original anatomy of this region of the skull. However, the short anterior process of the quadratojugal of GPIT/RE/7192 lacks a facet for reception of the posterior process of the jugal. A fairly complete, but still heavily covered by matrix, skull of $S$. stockleyi (NHMUK PV R2270) preserves an almost complete left jugal and a complete right jugal (Figure 3A: ju). The right jugal possesses a short and distally tapering posterior process that is restricted to the most anterior region of the ventral border of the infratemporal fenestra (Figure 3A: ppj). This process lacks facets for reception of an anterior process of the quadratojugal and, as a result, provides strong evidence that the lower temporal bar was open in S. stockleyi, as also occurs in M. browni (Dilkes, 1998), E. wolvaardti (Butler et al., 2015), R. articeps (NHMUK PV R1236, SHYMS 1, 3), and F. spenceri (EXEMS 60/1985.292; see above). In addition, an isolated rhynchosaur right jugal from the Manda beds (NHMUK R36840, potentially referable to $S$. stockleyi) also possesses a short posterior process without an articular facet (Figures 3C,F). This provides additional support for the presence of a rhynchosaur species with an open lower temporal bar in this unit.

The early Anisian rhynchosaurs from the Cynognathus AZ of South Africa possess numerous, well-developed palatal teeth (Broom, 1906; Dilkes, 1995, 1998; Butler et al., 2015). The absence of palatal dentition is universally accepted in B. sidensis, $F$. spenceri and Late Triassic rhynchosaurs (i.e., T. sulcognathus and Hyperodapedon spp; e.g., Montefeltro et al., 2010), but the situation in $R$. articeps and S. stockleyi has been matter of debate. Huxley (1887) described the presence of palatal teeth in $R$. articeps, but Benton (1990) reported that these supposed rows of palatine teeth were misinterpreted and actually represent the medial row of dentition on the maxillary tooth plate. Woodward (1907) also reported the presence of palatal teeth in this species, but he described the presence of "stumpy teeth" occurring along a pair of longitudinal ridges on the pterygoid (Woodward, 1907: 296, plate 2, Figure 1). The latter interpretation was supported by Huene (1929). Independently, Chatterjee (1969, 1974) described a single medial row of palatal teeth on the pterygoid of S. stockleyi. In a review of rhynchosaur evolution, Chatterjee (1980) described the presence of multiple rows in the palatal dentition in M. browni and H. browni, a single row in $R$. articeps and Stenaulorhynchus, and the absence of palatal teeth in Late Triassic species. Benton (1983b) considered the presence of a single row of palatal teeth on the pterygoid as a diagnostic feature of Rhynchosaurinae, a group that included R. articeps, S. stockleyi, and M. kuttyi. However, Benton (1990: 274) noted that the presence of palatal teeth in $R$. articeps and S. stockleyi "is not yet clearly demonstrated." Benton (1990) suggested that no adequately prepared specimen of S. stockleyi or $R$. articeps possesses palatal teeth, but that they do both possess a short pair of longitudinal ridges on the medial portion of the pterygoid. This interpretation was also supported by the absence of palatal dentition in the Middle Triassic F. spenceri and $B$. sidensis (Benton, 1990; Hone and Benton, 2008; Langer et al., 2010).

First hand re-examination of the palatal morphology of the best-preserved skull of S. stockleyi (GPIT/RE/7192) and a referred specimen of this species (NHMUK PV R2270) provides new information on the presence of palatal teeth in this taxon and in other basal rhynchosaurids. Our interpretation of the anatomy of these specimens indicates the presence of pair of anterolaterally-to-posteromedially oriented ridges on the ventral surface of the posterior half of the palatal process of the pterygoid (Figure 4), as described by Benton (1990) and also present in $R$. articeps (NHMUK PV R1236, see below). Both GPIT/RE/7192 and NHMUK PV R2270 possess a single row of distinct subcircular structures of a relatively homogeneous size along the apex of each pterygoid ridge, which are interpreted as palatal teeth (Figure 4: close-ups). In addition, adjacent to each ridge, both laterally and medially, the pterygoid of GPIT/RE/7192 is also covered with sub-circular structures with a relatively homogeneous size, but which do not form clear rows. The external morphology and arrangement of these structures present on the pterygoid of S. stockleyi (GPIT/RE/7192) resembles the palatal teeth of the rhynchosaurs from the early Anisian of South Africa (i.e., M. browni, H. browni) and provides strong evidence for the homology between these structures. Contrasting with the maxillary lingual teeth, the palatal teeth of S. stockleyi are not coated with a shiny cover that may represent enamel, but this could be a result of lack of preservation in available specimens. A shiny cover that may represent enamel is present on the palatal ridge of $R$. articeps (NHMUM R1236, see below).

\section{Anisian}

The rhynchosaur species $M$. kuttyi from India, and $R$. articeps and "Rhynchosaurus" brodiei from central England are dated as broadly Anisian in age based on long-range 


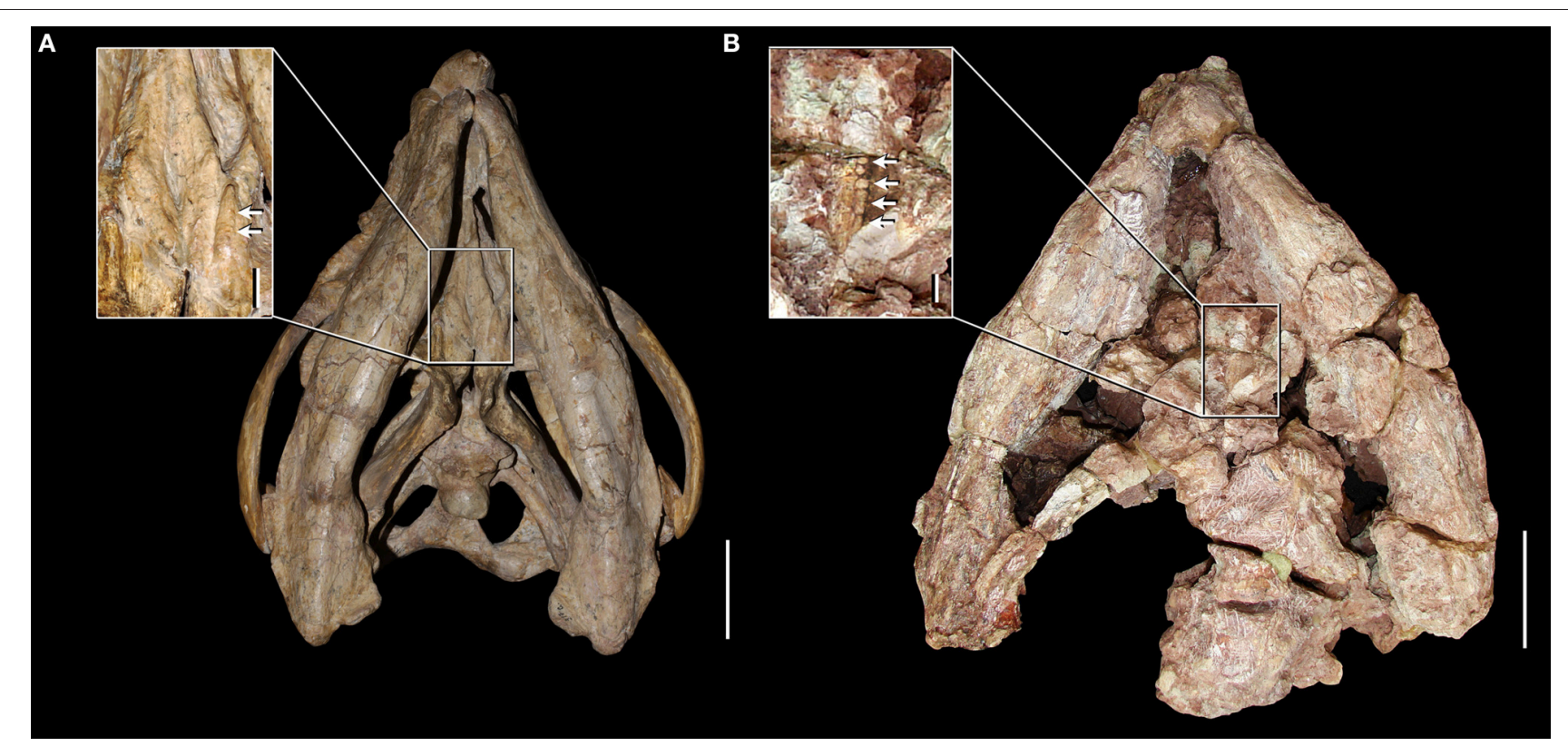

FIGURE 4 | Skulls and close-ups of the palatal morphology in ventral view of Stenaulorhynchus stockleyi from the late Anisian of Tanzania. GPIT/RE/7192 (A) and NHMUK PV R2270 (B). Arrows indicate pterygoid teeth. Scale bars equal to $5 \mathrm{~cm}$ in (A,B), $1 \mathrm{~cm}$ in close-up of (A), and $5 \mathrm{~mm}$ in close-up of (B)

biostratigraphical correlations, local lithostratigraphy and/or palynological evidence (Benton et al., 1994; Lucas, 2010; Table 1). As a result, their temporal relationship with the nonrhynchosaurid rhynchosaurs from the Cynognathus Assemblage Zone of South Africa and S. stockleyi from Tanzania is currently uncertain.

\section{Mesodapedon kuttyi}

Chatterjee (1980) erected the new rhynchosaur genus and species M. kuttyi based on a left dentary (ISI R300, holotype) and two referred right maxillae (ISI R301, 302) from the Anisian Yerrapalli Formation of central India. Unfortunately, these specimens could not be located in the collection of the ISI in February 2015 (MDE, pers. obs.). The general morphology of the maxilla and dentary of $M$. kuttyi strongly resembles those of $S$. stockleyi (e.g., NHMUK PV R9271, R9272, R9280, R9281) in the presence of two longitudinal grooves on the maxilla that reach the anterior half of the tooth plate and multiple rows of densely packed lingual teeth on the maxilla and dentary.

\section{Rhynchosaurus articeps}

The first rhynchosaur genus and species to be erected was $R$. articeps, which comes from a quarry at Grinshill, north of Shrewsbury, in central England (Owen, 1842a). The rhynchosaur-bearing levels at Grinshill belong to the Tarporley Siltstone Formation (Benton and Spencer, 1995) and 16 specimens are referred to the species (Benton, 1990). $R$. articeps was comprehensively redescribed in a monograph by Benton (1990) and is currently the best-known Middle Triassic rhynchosaurid. The anatomy of $R$. articeps was revisited after studying at first hand most of the available specimens and some comments and reinterpretations of its anatomy are made here.
The skull of $R$. articeps has been historically reconstructed with a complete lower temporal bar (e.g., Huene, 1938: Figure 10; Benton, 1990: Figure 2), resembling the condition in Late Triassic forms (e.g., Hy. gordoni: (Benton, 1983b); Hy. huxleyi: ISI R1; Hy. mariensis: MCZ 1636; Hy. sanjuanensis: MACN-Pv 18185). However, we could not find evidence for the presence of a jugal-quadratojugal contact in available specimens of $R$. articeps (SHYMS 1, 3; NHMUK PV R1236, 1237; Figures 5A,B). The posterior process of the jugal is short and posteriorly tapering (Figures 5A,B: ppj; SHYMS 1, 3; NHMUK PV R1236) and the anterior process of the quadratojugal is very low, developed as a semi-circular projection (Figure 5A: qj; SHYMS 1), closely resembling that of $E$. wolvaardti (Butler et al., 2015). As a result, we here interpret that a jugal-quadratojugal contact is absent in $R$. articeps and that the lower temporal bar is incomplete (Figure 6A), as occurs in M. browni (Dilkes, 1998), F. spenceri (EXEMS 60/1985.292; see above) and S. stockleyi (NHMUK PV R2270, R36840; see above).

A close examination of the palate in available specimens of $R$. articeps leads us to agree with Benton (1990) in the absence (or non-preservation) of palatal teeth and in the presence of a pair of anterolaterally-to-posteromedially oriented ridges on the ventral surface of the posterior half of the palatal process of the pterygoid (Figure 5C; NHMUK PV R1236). This pair of ridges on the pterygoid closely resembles the condition in Stenaulorhynchus stockelyi (GPIT/RE/7192), but it is not present in B. sidensis (BRSUG 27200; Hone and Benton, 2008), F. spenceri (EXEMS 60/1985.292; Benton, 1990), T. sulcognathus (Montefeltro et al., 2010), and Hyperodapedon spp. (Benton, 1983b; MACN-Pv 18185; MCZ 1636). These ridges clearly lack distinct, individual teeth, and they cannot be considered palatal dentition (cf. Benton, 1990). The possibility that these ridges are structures 


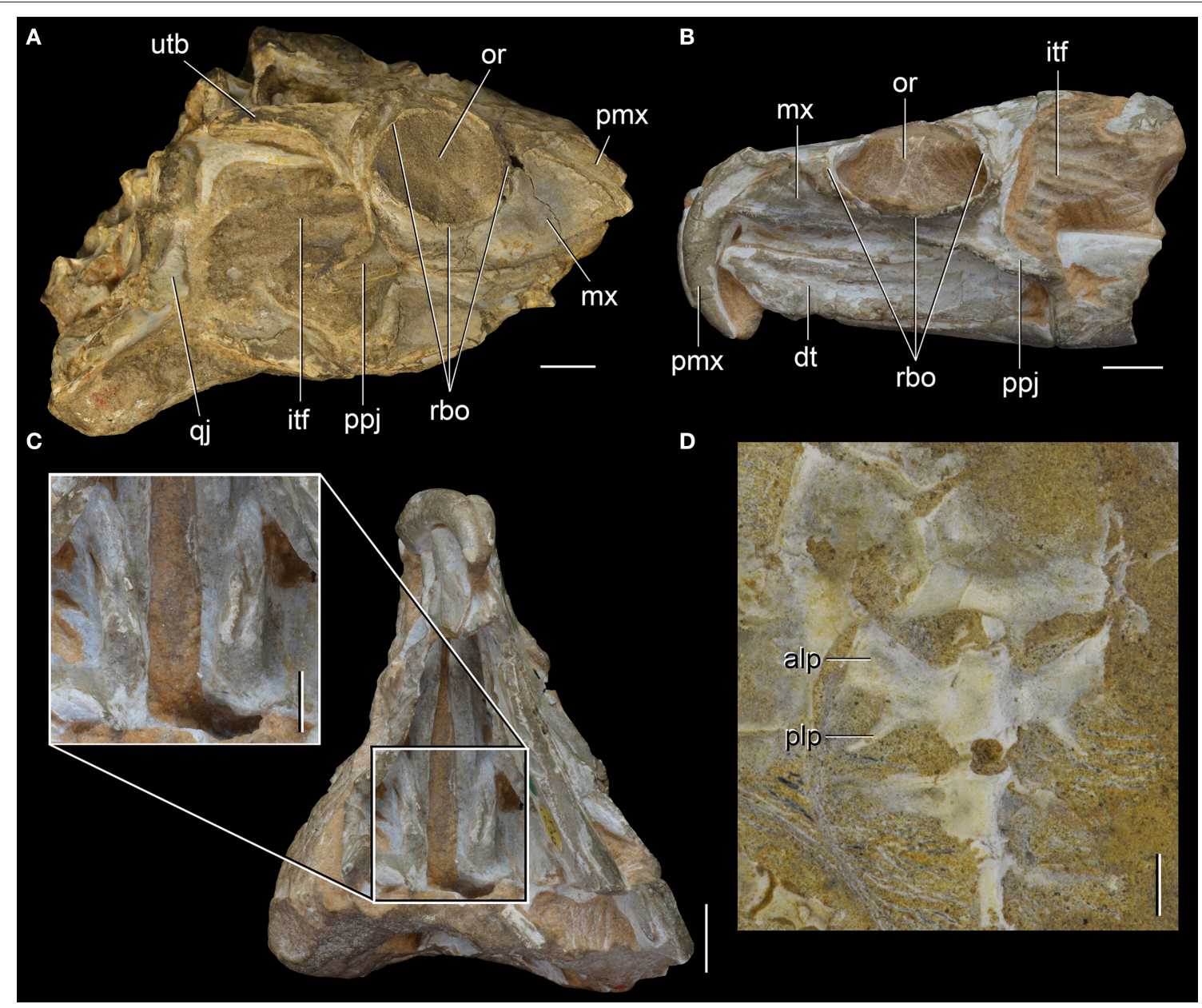

FIGURE 5 | Rhynchosaurus articeps from the Anisian of England. Partial skull (SHYMS 1, lectotype) in right lateral view (A), referred specimen NHMUK PV R1236 in left lateral (B) and ventral views, with close-up of palatal dental structure (C), and sacral vertebrae and first caudal of the referred specimen SHYMS 5 in ventral view (D). Abbreviations: alp, anterolateral process; dt, dentary; itf, infratemporal fenestra; mx, maxilla; or, orbit; plp, posterolateral process; pmx, premaxilla; ppj, posterior process of the jugal; qj, quadratojugal; rbo, raised border of the orbit; utb, upper temporal bar. Scale bars equal $1 \mathrm{~cm}$ in (A-C) and $5 \mathrm{~mm}$ in close-ups of $(\mathbf{C}, \mathbf{D})$

derived from fusion of rows of palatal teeth cannot currently be addressed because intermediate morphologies or histological data are absent in the currently available rhynchosaur sample. Nevertheless, it is striking that the pair of ridges present in the $R$. articeps specimen NHMUK PV R1236 possesses a shiny, white external surface that closely resembles the enamel present on the teeth of the maxillary tooth plate. As a result, it is possible that the ridges are covered with enamel, and, if so, this implies that they are structures derived from and homologous to the palatal dentition of the non-rhynchosaurid rhynchosaurs from the early Anisian of South Africa and S. stockleyi. This hypothesis could be tested in the future with analyses of the microstructure of these ridges or through discovery of better preserved specimens of $R$. articeps or basal rhynchosaurids preserving palatal dentition or homologous structures. Similarly, the palatal ridges that bear teeth in S. stockleyi (see above) are potentially homologous with those of $R$. articeps.
Benton (1990) described the second sacral rib of $R$. articeps as lacking the posterolateral projection (i.e., birfurcated distal end) present in S. stockleyi, and suggested that it instead resembled the condition in Late Triassic rhynchosaurs. Nevertheless, in the referred specimen SHYMS 5 we were able to confidently recognize the presence of a distal bifurcation in both sacral ribs of the second sacral vertebra (Figure 5D: plp), as occurs in several early archosauromorphs, South African rhynchosaurs, S. stockleyi and I. genovefae (Dilkes, 1998; Whatley, 2005; Ezcurra et al., 2015). The posterolateral projection of the second sacral rib of $R$. articeps curves gently laterally and tapers strongly distally in ventral view (SHYMS 5), resembling the condition in N. colletti (AM 3591), S. stockleyi (Huene, 1938) and some tanystropheids (e.g., Macrocnemus bessani: PIMUZ T2472). By contrast, Pamelaria dolichotrachela, Prolacerta broomi, M. browni, H. browni and an indeterminate archosauromorph from the Early-Middle Triassic of Argentina 


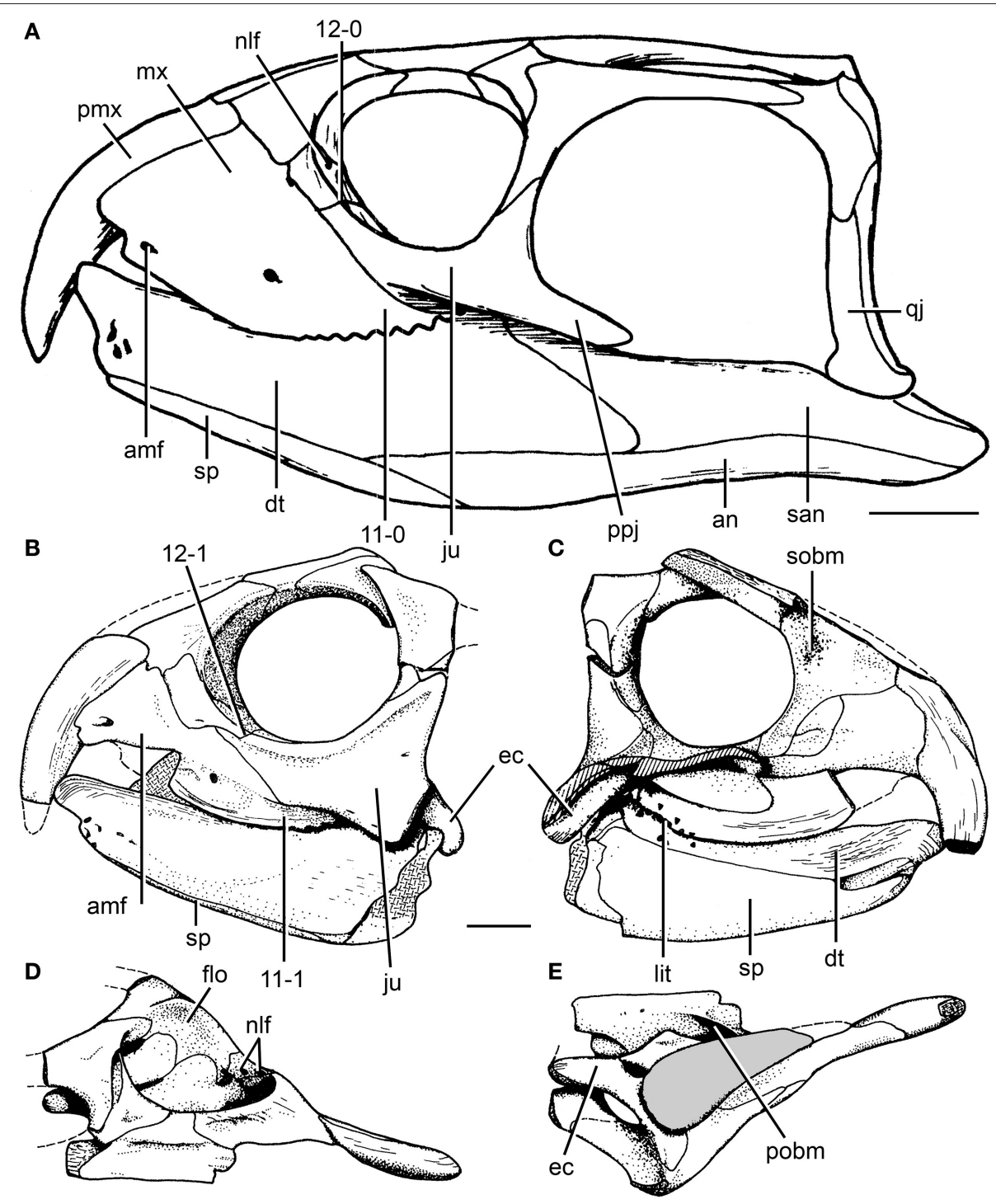

FIGURE 6 | Cranial reconstruction of Rhynchosaurus articeps and drawings of Langeronyx brodiei. R. articeps cranial reconstruction in left lateral view (A) and drawings of L. brodiei (WARMS G6097/1 and NHMUK PV R8495, holotype) in left lateral (B), left medial (C), dorsal (D), and ventral (E) views. Numbers indicate character-states synapomorphic of Langeronyx and rhynchosaurids to the exclusion of stenaulorhynchines and $R$. articeps. Abbreviations: amf, anterior maxillary foramen; an, angular; dt, dentary; ec, ectopterygoid; ju, jugal; flo, floor of the orbit; lit, lingual teeth; mx, maxilla; nlf, naso-lacrimal foramina; pmx, premaxilla; pobm, primary olfactory bulb mold; ppj, posterior process of the jugal; qj, quadratojugal; san, surangular; sobm, secondary olfactory bulb mold; sp, splenial. Scale bars equal $1 \mathrm{~cm}$. (A,E) modified from and (B-D) taken from Benton (1990).

possess a squared posterolateral projection (Ezcurra et al., 2015).

\section{“Rhynchosaurus" brodiei}

"Rhynchosaurus brodiei" was the second species described for the genus Rhynchosaurus (Benton, 1990) based on a fragmentary skull (holotype) and referred isolated elements from the Bromsgrove Sandstone Formation in Warwick, central England (Benton, 1990; Benton et al., 1994). Butler et al. (2015) provided for the first time positive evidence in favor of the paraphyly of the $R$. articeps + "Rhynchosaurus" brodiei clade, with the latter species placed as more closely related to hyperodapedontines and stenaulorhynchines than to $R$. articeps. Our revaluation of the holotype and referred specimens of "Rhynchosaurus" brodiei and its phylogenetic position provided strong evidence for the erection of a new genus for this species.

\section{SYSTEMATIC PALEONTOLOGY}

Diapsida Osborn (1903) sensu Laurin (1991)

Archosauromorpha Huene (1946) sensu Gauthier et al. (1988)

Rhynchosauria Osborn (1903) sensu Dilkes (1998)

Rhynchosauridae Huxley (1859) sensu Dilkes (1998)

Langeronyx gen. nov.

Figures 6B-E, 7, 8D 


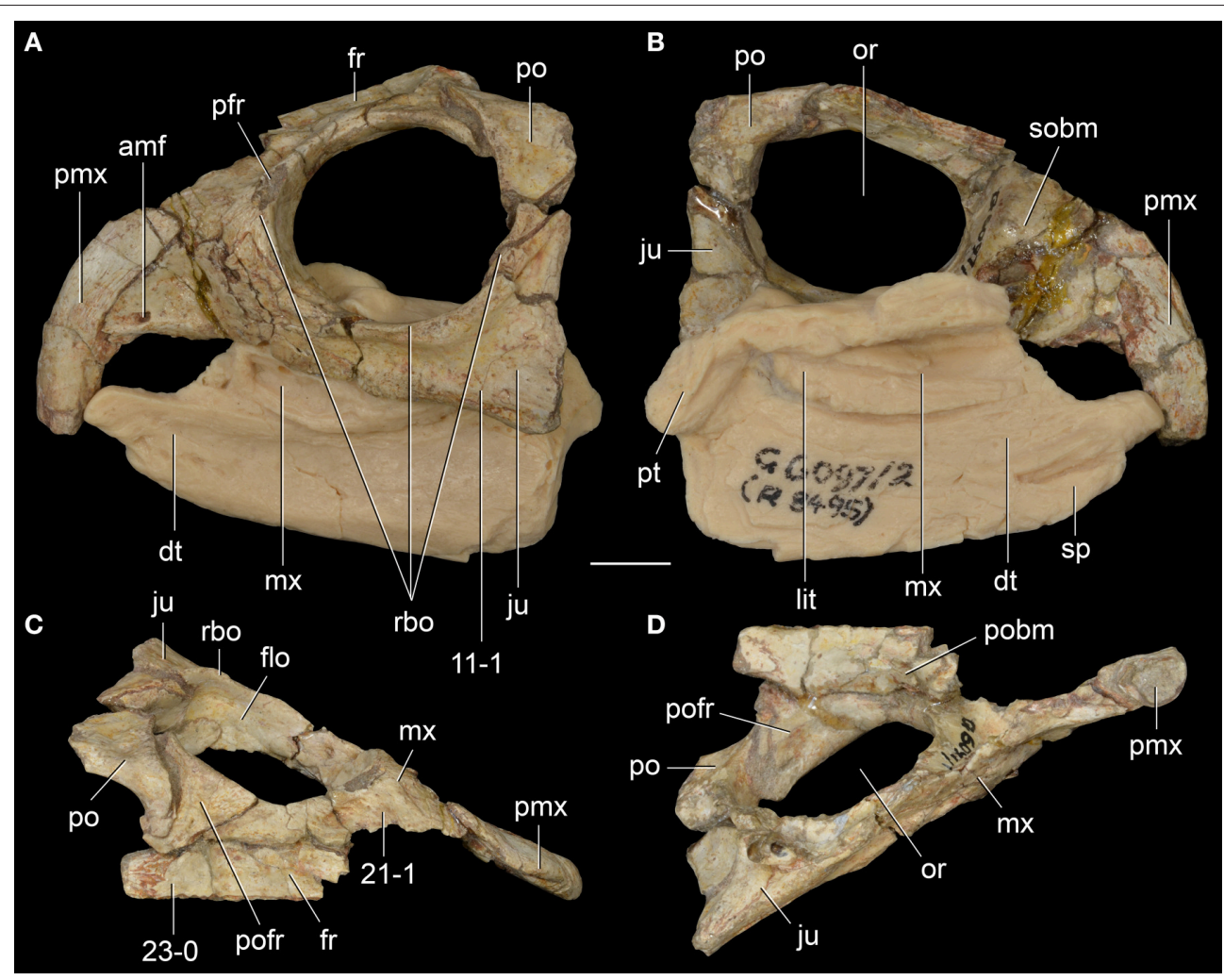

FIGURE 7 | Langeronyx brodiei nov. gen. et nov. comb. from the Anisian of England. WARMS G6097/1, G6097/2 (part of the holotype) in left lateral (A), left medial (B), dorsal (C), and ventral (D) views. Numbers indicate character-states synapomorphic of Langeronyx and rhynchosaurids to the exclusion of

stenaulorhynchines and Rhynchosaurus articeps. Abbreviations: amf, anterior maxillary foramen; dt, dentary; flo, floor of the orbit; fr, frontal; ju, jugal; lit, lingual teeth; mx, maxilla; or, orbit; po, postorbital; pofr, postfrontal; prf, prefrontal; pmx, premaxilla; pobm, primary olfactory bulb mold; pt, pterygoid; rbo, raised border of the orbit; sobm, secondary olfactory bulb mold. Scale bar equals $1 \mathrm{~cm}$.

1990 Rhynchosaurus Benton, p. 251.

Type species: Langeronyx brodiei (Benton, 1990).

Etymology: The new generic name Langeronyx is in honor of the Brazilian paleontologist Max Cardoso Langer, in recognition of his research on rhynchosaurs, combined with the Greek

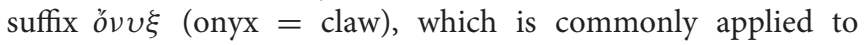
rhynchosaurs.

\section{L. brodiei (Benton, 1990)}

1990 Rhynchosaurus brodiei Benton, p. 251.

Holotype: The holotype of L. brodiei is housed in two institutions in the UK, WARMS G6097/1 (Warwickshire Museum, Warwick; Figure 7) and NHMUK PV R8495 (Natural History Museum, London). The two specimens represent two parts of a partial skull of a single individual that includes bones of the left side of the snout, orbital region, interorbital skull roof, palate and jaw apparatus (Figures 6B-E). The main portion of the skull is WARMS G6097/1 and includes the snout (premaxilla and ascending process of maxilla), skull roof (prefrontal, frontal and postfrontal), orbital region (jugal and postorbital), jugal ramus of the ectopterygoid and a fragment of maxilla with three teeth. The rest of the holotype, NHMUK PV R8495, includes a partial palate (pterygoid ramus of ectopterygoid, palatine and fragments of pterygoid) and a partial jaw apparatus (maxillary tooth plate, dentary, splenial and anterior portion of angular). Unfortunately,
NHMUK PV R8495 could not be located in the collection during several visits to the NHMUK PV between 2014-2015 (MDE pers. obs.). Anatomical information for this specimen is based therefore on a cast of the specimen housed at the Warwickshire Museum (WARMS G6097/2) and the description and figures published by Benton (1990).

Previously referred specimens: Benton (1990) referred several isolated cranial and postcranial bones and a couple of partial rostra from Warwick to "Rhynchosaurus" brodiei. Some of these specimens (WARMS G17, G19, G34) do not overlap with the holotype of the species and because of the presence of more than one rhynchosaur species in coeval stratigraphic units of the UK (i.e., the Otter Sandstone Formation) and a second basal archosauromorph in the Bromsgrove Sandstone Formation (Rhombopholis scutulata; Owen, 1842b; Benton and Walker, 1996), we suggest that these specimens cannot be assigned unambiguously to L. brodiei. Regarding the specimens that do overlap with the holotype of L. brodiei, their morphology is also congruent with that of other basal rhynchosaurids (e.g., F. spenceri, B. sidensis) and there is no unique combination of character states that may allow their unambiguous assignment to L. brodiei (WARMS G950-1, G955, G959, G960, G4712, G4715). For example, two isolated dentaries (WARMS G950-1, G959) possess a morphology consistent with that of F. spenceri (EXEMS 


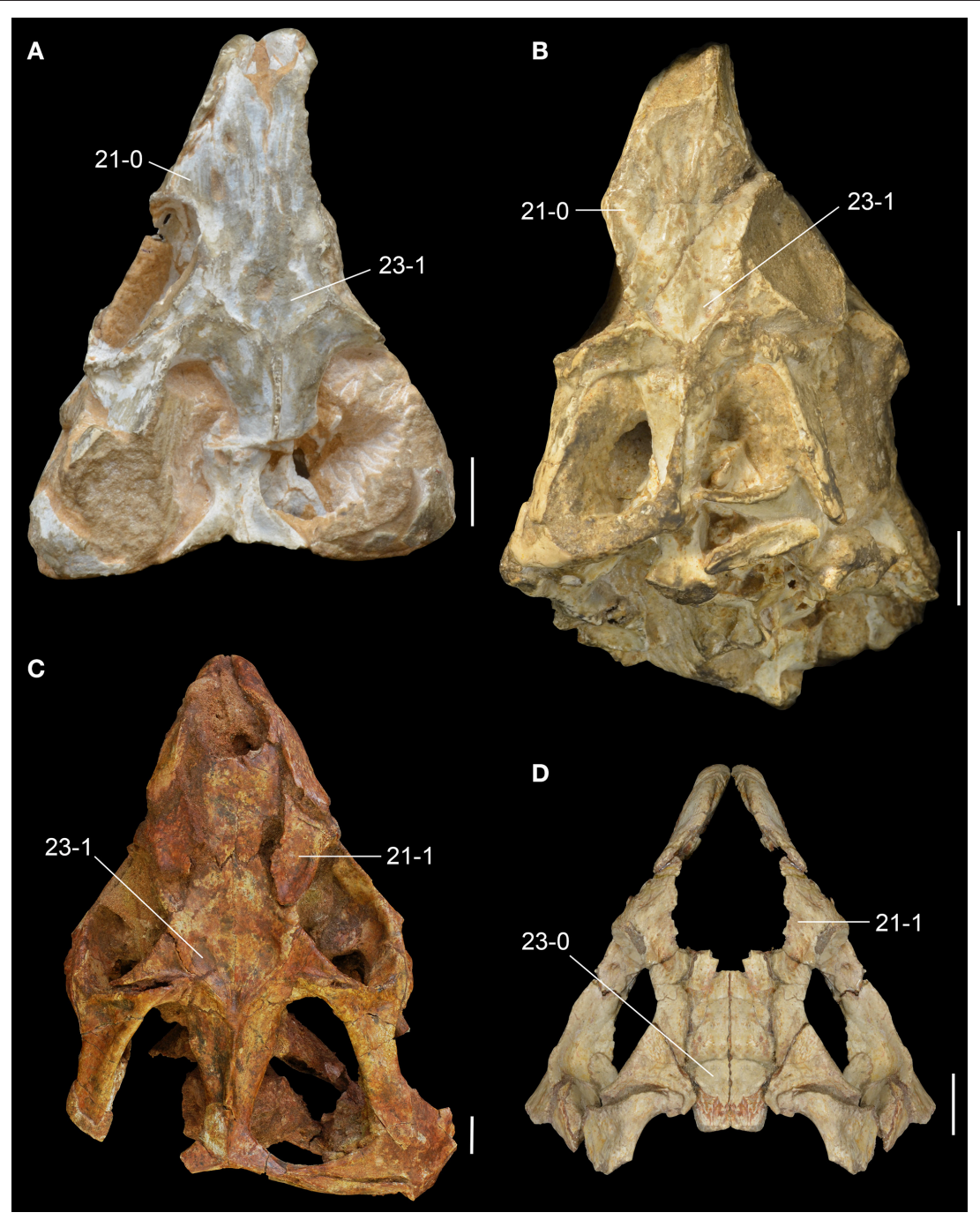

FIGURE 8 | Middle Triassic rhynchosaur skulls compared in dorsal view. Rhynchosaurus articeps (A: NHMUK PV R1236; B: SHMYS 1, lectotype), Bentonyx sidensis (C: BRSUG 27200, holotype), and Langeronyx brodiei (D: WARMS G6097/1, holotype, right side mirrored from preserved left side). Numbers indicate character-states synapomorphic of $L$. brodiei and rhynchosaurids to the exclusion of stenaulorhynchines and $R$. articeps. Scale bars equal $1 \mathrm{~cm}$.

60/1985.292). Two isolated, partial maxillae from Bromsgrove were also referred to "Rhynchosaurus" brodiei by Benton (1990) but their morphology is also congruent with that of other basal rhynchosaurids (Benton, 1990: Figure 26). As a result, we consider that there is no currently known specimen that can be unambiguously referred to L. brodiei and restrict the species to the holotype only.

Horizon and locality: Coten End Quarry (SP 289655), Warwick, Warwickshire, UK. The specimens were collected in the Finstall Member (formerly called the "Building Stones") of the Bromsgrove Sandstone Formation (formerly the "Keuper Sandstone”), Anisian (Benton et al., 1994, 2002).

Diagnosis: Langeronyx (and L. brodiei by monotypy) is a medium-sized rhynchosaur (estimated skull length $140 \mathrm{~mm}$; Benton, 1990) that differs from other rhynchosaurs in the following combination of character states: laterally facing and sub-circular orbit with a raised and thickened border that is less marked along the postorbital bone than other parts of the orbital margin; anterior process of the jugal dorsoventrally tall, in which the ratio between the height of the base of the anterior process and the anteroposterior length of the orbit is 0.37 , with this process being exposed more broadly than the maxilla in lateral view; dorsal surface of the prefrontal deeply concave; dorsal surface of the frontal slightly concave transversely; occlusal dentition of maxilla composed of two tooth-bearing areas separated by a single well-delimited longitudinal sulcus; maxillary lateral tooth-bearing area is crest-shaped; lingual maxillary teeth scattered, do not form clear rows and are not regularly spaced; lingual dentary teeth conical and of similar size to the occlusal teeth.

\section{New observations on the anatomy of Langeronyx brodiei}

The reassessment of WARMS G6097/1 and WARMS G6097/2 (cast of NHMUK PV R8495) sheds new light on the anatomy 
of the species, revealing unreported anatomical features and reinterpretation of some characters. As noted by Benton (1990), the skull of $L$. brodiei possesses a proportionately shorter rostrum than in $R$. articeps (e.g., SHYMS 1, 3; Figure 6), which makes the general appearance of the species more similar to rhynchosaurids with a massive and shortened skull (e.g., B. sidensis: BRSUG 27200; S. stockleyi: GPIT/RE/7192).

The sub-circular orbit is fully laterally facing as in other basal rhynchosaurs and has a raised and thickened border (Figure 7A: rbo), as occurs in R. articeps (SHYMS 1), S. stockleyi (GPIT/RE/7192) and B. sidensis (BRSUG 27200). However, the thickening of the border is less marked along the postorbital bone, contrasting with the other taxa, in which the thickening is equally well-developed around the entire circumference of the orbit. The rostrum of L. brodiei is formed by the nearly complete downturned premaxilla and the ascending process of the maxilla. The lateral surface of the maxilla overlaps the premaxilla laterally and is pierced by a large anterior maxillary foramen a few millimeters posterior to the contact with the premaxilla (Figures 6B, 7A: amf).

The maxillary occlusal margin is markedly curved in lateral view. This is the typical rhynchosaurid morphology (Langer et al., 2000b; Nesbitt and Whatley, 2004), but differs from the more gentle curvature of $H$. browni and E. wolvaardti and the completely straight margin of M. browni (Benton, 1983b, 1990; Dilkes, 1995, 1998; Langer and Schultz, 2000; Montefeltro et al., 2010; Mukherjee and Ray, 2014; Butler et al., 2015). The posterior end of the maxilla is dorsoventrally shallower ventrally to the jugal than in E. wolvaardti (SAM-PK-K10159) and R. articeps (SHYMS 1, NHMUK PV R1236; Figure 6). The condition in $L$. brodiei seems to be more similar to the morphology in stenaulorhynchines and hyperodapedontines. However, this feature is hard to quantify and might be directly linked to the dorsoventrally deeper anterior process of the jugal in L. brodiei, stenaulorhynchines and hyperodapedontines (Butler et al., 2015).

As in all other rhynchosaurids, the triangular maxillary tooth plate is broadly exposed on the skull of $L$. brodiei in ventral view (Chatterjee, 1969, 1974, 1980; Dilkes, 1995, 1998; Langer and Schultz, 2000; Nesbitt and Whatley, 2004; Montefeltro et al., 2010). The medial limit of the maxilla is the medial margin of the maxillary tooth plate, except in its posteromedial corner, where the maxilla extends for a short distance and participates in the border of the suborbital fenestra, as also occurs in $M$. browni and H. browni (Dilkes, 1995, 1998; Langer and Schultz, 2000; Montefeltro et al., 2010). The occlusal surface of the maxilla is not fully exposed because of the attached lower jaw, but both occlusal and lingual dentitions are present (see below).

The jugal is the most broadly exposed element anterior to the infratemporal fenestra in lateral view (Figures 6B, 7A). This feature was considered to distinguish the species from other species of Rhynchosaurus in the original description (Benton, 1990), and was recently considered a synapomorphy of taxa more derived than $R$. articeps, including $L$. brodiei and F. spenceri (Langer et al., 2010; Butler et al., 2015). The ratio between the dorsoventral depth of the base of the anterior process of the jugal and the anteroposterior length of the orbit is 0.37 in L. brodiei.
This ratio in the lectotype of $R$. articeps (SHYMS 1 ) is 0.24 and in the more complete and undistorted referred specimen NHMUK PV R1236 is 0.30 . The jugal forms most of the ventral margin of the orbit but the anteroventral corner is formed by the lacrimal (Benton, 1990).

The ventral margin of the anterior process of the jugal is laterally displaced in relation to the lateral surface of the maxilla. At the boundary between the jugal and the maxilla there is a welldelimited anguli oris crest. However, we cannot confirm if this structure is limited to the main body of the jugal, as in S. stockleyi, $B$. sidensis, and F. spenceri, if it extended onto the maxilla, as in E. wolvaardti and $R$. articeps, or if it extended onto the infraorbital process of the jugal as in I. genovefae, T. sulcognathus, and Hyperodapedon spp. (Butler et al., 2015). The dorsal process of the jugal extends beyond the level of the mid-height of the orbit (Figure 6B), contrasting with the proportionally shorter process of the lectotype of $R$. articeps (Figure 5A; SHYMS 1), but resembling the $R$. articeps referred specimen NHMUK PV R1236 (Figure 5B). Only the base of the posterior process of the jugal is preserved in L. brodiei (WARMS G955) and, as a result, we cannot determine if the infratemporal fenestra was open or closed. The posterior process of the jugal is ventrolaterally directed at its base with respect to the sagittal axis of the snout, as in all other rhynchosaurids (Butler et al., 2015).

The prefrontal and lacrimal are exposed in both lateral and medial views. In lateral view, these bones form a smooth surface at the anterodorsal corner of the orbit. The same morphology is present in M. browni, R. articeps, and S. stockleyi, but it differs from the protruding dorsolateral orbital corner of hyperodapedontines (Benton, 1983b; Dilkes, 1998; Langer and Schultz, 2000; Whatley, 2005; Montefeltro et al., 2010). The anterior process of the jugal contacts the ventral and anteroventral borders of the lacrimal in lateral view, which results in an extensive suture (Figure 6B). This condition resembles the extensive sutural contact between these bones present in $B$. sidensis and hyperodapedontines (Whatley, 2005; Langer et al., 2010; Montefeltro et al., 2010), but contrasts with the more restricted contact between lacrimal and jugal present in $R$. articeps (Figure 6A). The lacrimal medial shelf at the floor of the orbit has a pair of foramina for the exit of the naso-lacrimal duct (Figure 6D: nlf). The foramina are subequal in size and oval, with a dorsoventrally oriented main axis.

The prefrontal is broadly exposed on the lateral surface of the skull, resembling the condition in M. browni (SAM-PK-6536) and $R$. articeps (SHYMS 1), whereas other rhynchosaurids have a greater dorsal exposure of the prefrontal (Langer and Schultz, 2000; Hone and Benton, 2008; Montefeltro et al., 2010). The dorsal surface of the prefrontal is deeply concave in L. brodiei (Figure 8D: 21-1), as also occurs in S. stockleyi (GPIT/RE/7192), B. sidensis (BRSUG 27200), T. sulcognathus (UFRGS-PV-0232, UFRGS-PV-0298), and Hyperodapedon spp. (FZB-PV-1867; PVSJ 680; UFRGS-PV-0408; Chatterjee, 1974; Benton, 1983b). In medial view, the ventromedial surface of the prefrontal of L. brodiei is mostly covered by a distinct rounded depression that housed the left secondary olfactory bulb (Figures 6C, 7B: sobm; Benton, 1990). The same structure is present as a natural mold in E. wolvaardti (SAM-PK-K10159, Butler et al., 2015) 
and would have occupied an equivalent position to that in $L$. brodiei. The position of the secondary olfactory bulb in these rhynchosaurs resembles that of other basal archosauromorphs (e.g., Tasmaniosaurus triassicus; Ezcurra, 2014), but distinctly differs from the olfactory bulb of $T$. sulcognathus (UFRGSPV-0232) reconstructed from CT data, which is placed more posteriorly at the level of the mid-length of the orbit (Sales and Schultz, 2014).

The left frontal is almost complete in WARMS G955, with exception of its anteromedial tip. Its dorsal surface is only slightly transversely concave (Figures 7C, 8D: 23-0), as in $S$. stockleyi (GPIT/RE/7192), T. sulcognathus (UFRGS-PV-0232, UFRGS-PV-0298), Hyperodapedon huenei (UFRGS-PV-0132), and Hy. mariensis (FZB-PV-1867). This condition differs from the clearly delimited posterior depression on the frontal of $R$. articeps (Figures 8A,B: 23-0; SHYMS 1), and B. sidensis (Figure 8C: 23-1; BRSUG 27200), or the longitudinal depression along the entire frontal surface in $M$. browni (SAM-PK6536), H. browni (Dilkes, 1995), and Hy. gordoni (Benton, 1983b). The postfrontal exhibits postmortem distortion and its original relationships with the surrounding bones cannot be exactly restored.

The preserved palatal region of $L$. brodiei is restricted to the ectopterygoid and fragments of the palatine and pterygoid attached to the maxillary tooth plate and ectopterygoid (Figures 6B-E). The ectopterygoid was probably restricted to the posterolateral portion of the palate, as in all other rhynchosaurs, and to the lateral corner of the transverse flange of the pterygoid, as in all rhynchosaurids (Dilkes, 1995, 1998; Langer and Schultz, 2000; Montefeltro et al., 2010). The lateral process of the ectopterygoid extends laterally contacting the jugal in a posteroventrally to anterodorsally directed suture and forming a small part of the orbital floor. The medial portion of the ectopterygoid overlaps ventrally the preserved portion of the lateral process of the pterygoid. Anteriorly, the medial portion of the ectopterygoid attaches to the posterolateral corner of the maxillary tooth plate, not contacting the palatine at the border of the suborbital fenestra.

The holotype of L. brodiei preserves most of the dentary and splenial, and also a small portion of the angular and coronoid (Figures 6B,C, 7A,B). Thus, some basic measurements cannot be inferred from the specimen (e.g., ratio between mandible depth and length, and percentage of the mandible formed by the dentary). The anterior region of the dentary in L. brodiei is typical of rhynchosaurids. The dentaries diverge anteriorly before reaching the symphyseal region, which is formed only by the splenials (Benton, 1990; Dilkes, 1998; Montefeltro et al., 2010). The dentition is placed on both occlusal and lingual surfaces of the dentary (see below). The splenial overlaps the dentary medially, covering most of its medial surface, and does not show any trace of an anterior Meckelian foramen. The coronoid and the angular are preserved as fragments posterior to the dentary and splenial, but no useful information can be recovered from those bones.

The dentition of $L$. brodiei is partially hidden in the holotype (NHMUK PV R8495), but the typical general dental morphology of rhynchosaurids is visible (e.g., an edentulous downturned premaxilla and a blade and groove jaw apparatus, with the dentary blade fitting precisely in the maxillary groove).

The maxillary occlusal dentition of $L$. brodiei is composed of two tooth-bearing areas separated by a single well-delimited longitudinal sulcus. Our interpretation is in accordance with recent studies (Montefeltro et al., 2010, 2013; Butler et al., 2015), but differs from more orthodox interpretations in which all Middle Triassic rhynchosaurids were depicted with two longitudinal maxillary sulci (Chatterjee, 1969, 1980; Benton, 1983b, 1984, 1985, 1988, 1990; Dilkes, 1995, 1998). The lateral tooth bearing area is narrower than the medial one, as occurs in S. stockleyi, F. spenceri, T. sulcognathus, and Hyperodapedon huenei. By contrast, in I. genovefae, A. navajoi, Hy. mariensis, Hy. sanjuanensis, Hy. gordoni, Hy. huxleyi, and Hyperodapedon tikiensis the lateral tooth bearing area is equal to or more developed than the medial area (Langer and Schultz, 2000; Langer et al., 2000b, 2010; Nesbitt and Whatley, 2004; Montefeltro et al., 2010; Mukherjee and Ray, 2014). The lateral tooth bearing area is crest-shaped, as in $R$. articeps, $S$. stockleyi, B. sidensis, T. sulcognathus, and Hyperodapedon huenei (Montefeltro et al., 2010). On the lingual surface of the maxilla there are scattered lingual teeth that do not form clear rows and are not regularly spaced (Figures 6C, 7B: lit), resembling the condition in F. spenceri and B. sidensis (Langer et al., 2010; Montefeltro et al., 2010; Butler et al., 2015).

The dentary dentition of $L$. brodiei is formed by both occlusal (buccal teeth sensu Benton, 1984) and lingual teeth as in most rhynchosaurids (Figures 6C, 7B: lit), with the exception of $\mathrm{Hy}$. sanjuanensis, which lacks lingual teeth (Langer and Schultz, 2000; Langer et al., 2000b). The occlusal teeth are not completely exposed in L. brodiei (Benton, 1990). The anterior tip of the dentary is completely devoid of teeth (Benton, 1990). The dentary of $L$. brodiei possesses broadly spaced primary lingual teeth (sensu Langer and Schultz, 2000) on the medial wall of the dentary (Benton, 1990). These teeth are slightly smaller than the more lateral lingual teeth and do not form clear rows (Benton, 1990). This condition differs from the large number of heavily packed primary dental teeth of S. stockleyi, F. spenceri, and T. sulcognathus (Montefeltro et al., 2010; Langer et al., 2010; Butler et al., 2015).

\section{DISCUSSION}

\section{Phylogenetic Relationships of Early Rhynchosaurs and the Paraphyly of Rhynchosaurus}

The parsimony analysis yielded two most parsimonious trees (MPTs) of 148 steps with a consistency index (CI) of 0.6959 and a retention index (RI) of 0.7761 . The topology of the strict consensus tree of the MPTs recovered here (Figure 9) is congruent with the single MPT found by Butler et al. (2015), but less resolved. The inclusion of $N$. colletti resulted in a large polytomy at the base of Rhynchosauria, which includes all non-rhynchosaurid rhynchosaurs. $N$. colletti is recovered in three possible alternative positions, namely as the sister taxon of M. browni, sister taxon of E. wolvaardti + Rhynchosauridae 


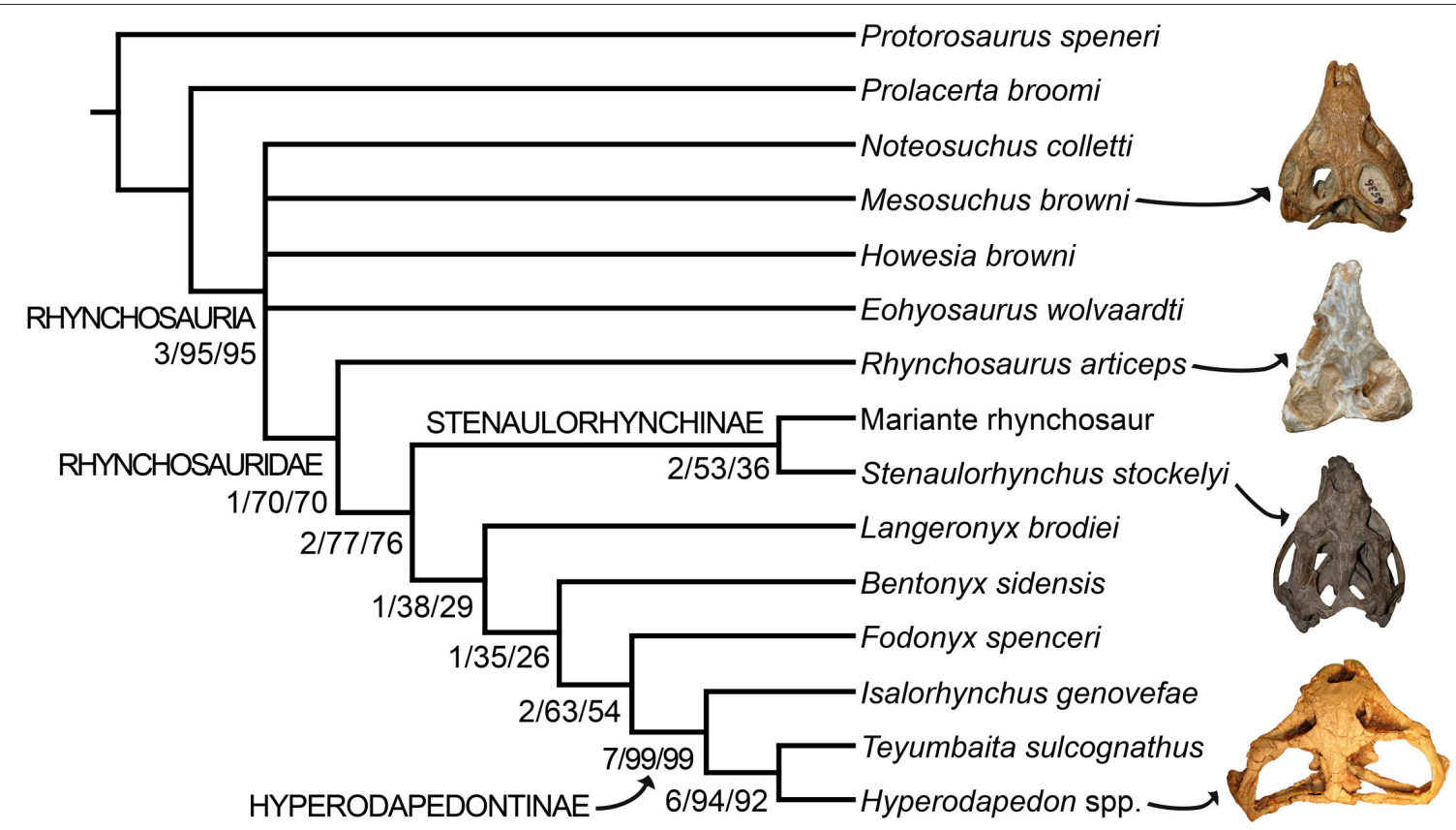

FIGURE 9 | Strict consensus tree showing the phylogenetic relationships of rhynchosaurs recovered here. Numbers below the nodes are Bremer support, absolute bootstrap and GC bootstrap resampling frequencies, respectively. The skulls figured to the right of the cladogram belong to, from the top to bottom, Mesosuchus browni (SAM-PK-6536), Rhynchosaurus articeps (NHMUK PV R1236), Stenaulorhynchus stockleyi (GPIT/RE/7192), and Hyperodapedon mariensis (MCZ 1636).

or sister taxon of Rhynchosauridae. The polytomy at the base of Rhynchosauria is resolved when $N$. colletti is pruned a posteriori but before generating the strict consensus tree. The resultant topology of this part of the strict reduced consensus tree is identical to that obtained by Butler et al. (2015) (i.e., M. browni, H. browni and E. wolvaardti as successive sister taxa of Rhynchosauridae). The inclusion of $N$. colletti within Rhynchosauria is supported by two synapomorphies: pubic tubercle on the lateral surface of the shaft (character-state 89: $1 \rightarrow 0$ ) and metatarsal I vs. metatarsal III length ratio $<0.45$ (character-state 96: $1 \rightarrow 0$ ). The sister-taxon relationship between $N$. colletti and M. browni is supported by the presence of a median longitudinal groove on the ventral surface of the centrum of the first two caudals (character-state 95: 0-1). Alternatively, the position of $N$. colletti as more closely related to M. browni, $H$. browni and ambiguously to E. wolvaardti (because of missing data in this species) is supported by the presence of a tapering posterior projection of the bifurcated distal end of the second sacral rib (character-state 94: $1 \rightarrow 0$ ). Three additional steps are required to force the position of $N$. colletti outside Rhynchosauria and only one to be placed at the base of the clade.

As previously recognized by Butler et al. (2015), Rhynchosaurus is found as a paraphyletic genus, in which L. brodiei (= "Rhynchosaurus" brodiei) is recovered as more closely related to hyperodapedontines than to $R$. articeps. The clade composed of L. brodiei and other rhynchosaurids to the exclusion of $R$. articeps is supported by six synapomorphies, three of which are present in the former species (the other three synapomorphies are not preserved): jugal higher than maxilla below the ventral border of the orbit (character-state 11: $0 \rightarrow 1$ ); prefrontal with a deeply concave dorsomedial surface near the orbital rim (character-state $21: 0 \rightarrow 1$ ); and frontal without a groove on its dorsal surface (character-state 23: $1 \rightarrow 0$ ). Butler et al. (2015) found a polytomy composed of $L$. brodiei, stenaulorhynchines and species more closely related to hyperodapedontines than to the former clades. However, this part of the tree is resolved in the new analysis and L. brodiei is recovered as more closely related to hyperodapedontines than to stenaulorhynchines. The clade composed of $L$. brodiei and other rhynchosaurids to the exclusion of $R$. articeps and stenaulorhynchines is supported by a single synapomorphy: extensive contact of the jugal anterior process with the lacrimal (character-state 12: $0 \rightarrow 1$ ). Under constrained topologies, one additional step is necessary to force the position of $L$. brodiei within Stenaulorhynchinae, as the sister taxon of all other rhynchosaurids to the exclusion of $R$. articeps, as the sister taxon of B. sidensis, or as the sister taxon of Fodonyx and hyperodapedontines. By contrast, four additional steps are necessary to force a sister-taxon relationship between $R$. articeps + L. brodiei (Templeton test using Wilcoxon signed-ranks, $p=0.0455$ ). Therefore, the results recovered here are generally congruent with the most recent phylogenetic hypotheses [i.e., Langer et al., 2010; Montefeltro et al., 2013; Butler et al., 2015; but see Mukherjee and Ray (2014) for a different result] and support the erection of a new genus for "Rhynchosaurus" brodiei.

It is worth noting that the anatomical reinterpretations reported here resulted in changes in scorings from previous data matrices and in the optimization of characters. The closure of 
A

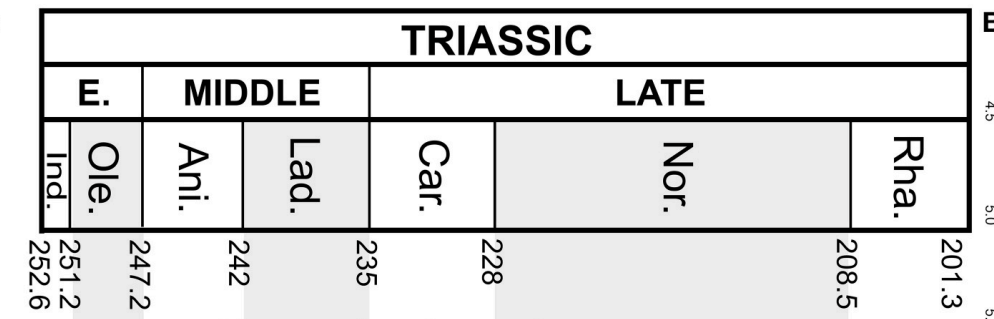

\section{B}

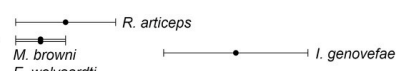

M. wolvaardti I. genovefae

L. brodiei $\because$ F spenceri
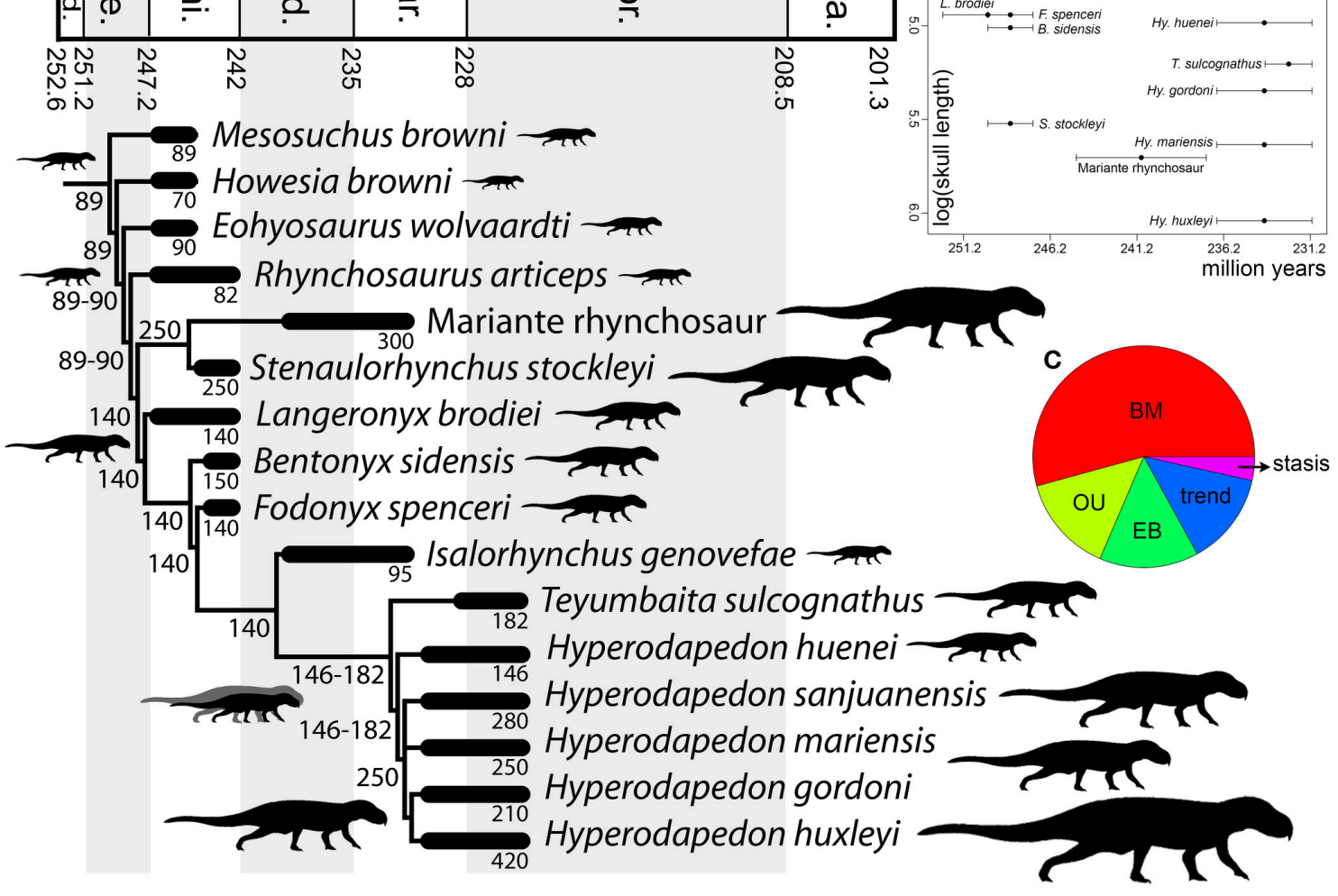

FIGURE 10 | Body size analyses results. Time-calibrated informal supertree showing the optimization of skull length through rhynchosaur evolution (A), bivariate plot showing log (skull length) vs. temporal calibration of taxa (horizontal error bars indicate chronostratigraphic uncertainty) (B), and relative support for evolutionary model fit analysis using mean ages (C). Abbreviations: Ani, Anisian; BM, Brownian motion; Car, Carnian; EB, Early Burst; Ind, Induan; Lad, Ladinian; Nor, Norian; Ole, Olenekian; OU, Ornstein-Uhlenbeck; Rha, Rhaetian.

the lower temporal bar was previously interpreted as a character state that appeared early in rhynchosaur evolution, being optimized as an apomorphy of Rhynchosauridae (e.g., Benton, 1990; Dilkes, 1998). However, the new analysis indicates that rhynchosaurs with a closed lower temporal bar are restricted to Hyperodapedontinae and probably the "Mariante rhynchosaur." Similarly, the absence of pterygoid dentition was interpreted as a synapomorphy of Rhynchosauridae (e.g., Benton, 1990; Dilkes, 1998), but changes in scorings in $R$. articeps and S. stockleyi result here in its optimization as a synapomorphy of rhynchosaurids to the exclusion of $R$. articeps and stenaulorhynchines. As a result, these two characters with potentially strong paleocological implications seem to have appeared later in rhynchosaur evolution than previously thought.

\section{Macoevolutionary History of Early Rhynchosaurs Body Size Evolution}

The optimization of skull length (as a proxy of body size) in the phylogenetic tree suggests that a cranial length of $\sim 90 \mathrm{~mm}$ represents the ancestral condition for Rhynchosauria, and that this was retained up to the base of Rhynchosauridae (Figure 10A). Indeed, non-rhynchosaurid rhynchosaurs and $R$. articeps possess skull lengths that range from 70 to $90 \mathrm{~mm}$. An increase to an ancestral skull length of $140 \mathrm{~mm}$ was reconstructed for the node that includes stenaulorhynchines and hyperodapedontines, and is retained up until the clade composed of I. genovefae, T. sulcognathus, and Hyperodapedon spp. A conspicuous reduction to a skull length of $95 \mathrm{~mm}$ is optimized as an autapomorphy of I. genovefae among hyperodapedontines. Two independent increases in body size are reconstructed in the evolutionary history of Rhynchosauridae. The first is represented by stenaulorhynchines (i.e., S. stockleyi and the Mariante rhynchosaur; with an ancestral skull length of $250 \mathrm{~mm}$ ) and the second in members of the clade that includes $T$. sulcognathus and Hyperodapedon spp. (ancestral skull length of $146-182 \mathrm{~mm}$ ), which is clearer for the node composed of all species of Hyperodapedon with exception of Hyperodapedon huenei (ancestral skull length of $250 \mathrm{~mm}$ ). As a result, these two clades independently acquired a skull length more than 
TABLE 2 | Fit of four different models to the body size evolutionary history of Rhynchosauria.

\begin{tabular}{|c|c|c|c|c|c|c|c|c|c|c|}
\hline \multirow[t]{2}{*}{ Time calib. } & \multicolumn{2}{|c|}{ BM } & \multicolumn{2}{|c|}{ OU } & \multicolumn{2}{|c|}{ EB } & \multicolumn{2}{|c|}{$\mathrm{BM}+$ trend } & \multicolumn{2}{|c|}{ Stasis } \\
\hline & AICc & $\%$ & AICc & $\%$ & AICc & $\%$ & AICc & $\%$ & AICc & $\%$ \\
\hline Mean & 22.447 & 54.264 & 25.116 & 14.289 & 25.092 & 14.457 & 25.226 & 13.520 & 27.947 & 03.469 \\
\hline Upper & 47.550 & $<0.001$ & 46.932 & $<0.001$ & 41.549 & 00.001 & 44.580 & $<0.001$ & 27.947 & 99.851 \\
\hline Lower & 21.767 & 55.360 & 24.065 & 17.543 & 24.744 & 12.493 & 24.811 & 12.085 & 27.947 & 02.519 \\
\hline Upper* & 29.813 & 00.392 & 32.111 & 00.124 & 25.676 & 03.101 & 25.984 & 02.658 & 18.859 & 93.725 \\
\hline
\end{tabular}

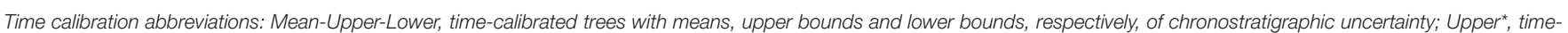

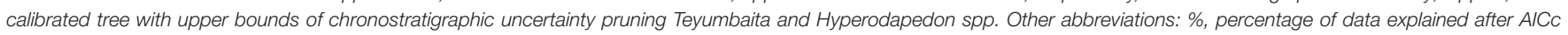
weights; AlCc, mean of the corrected Akaike's Information Criterion; BM, Brownian motion; calib, calibration; EB, early burst; OU, Ornstein-Uhlenbeck.

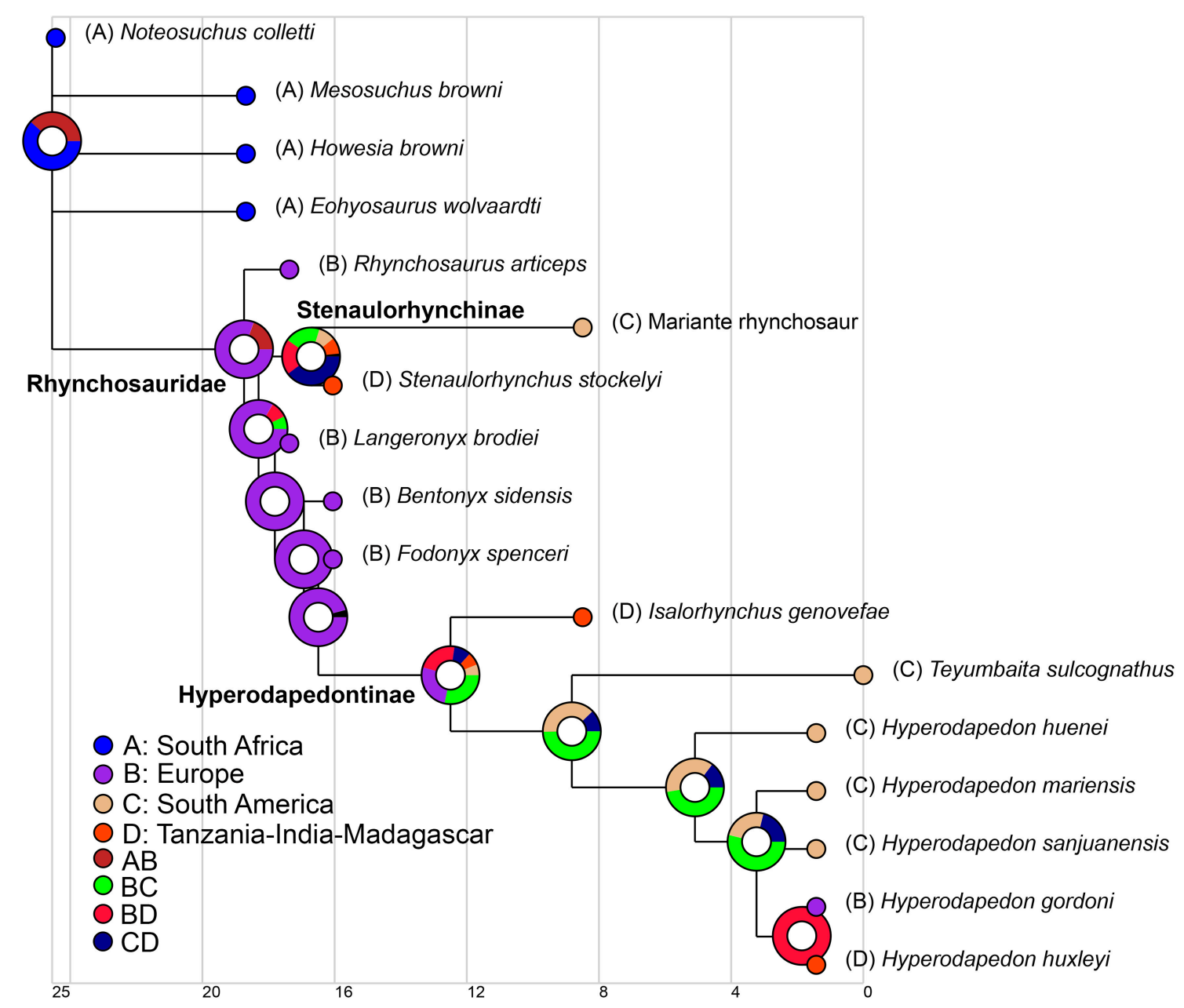

FIGURE 11 | Paleobiogeographic analysis of rhynchosaurs based on a global phylogeny of the group. Results obtained from DEC (Dispersion-Extinction-Cladogenesis) analysis. The temporal scale at the bottom is in millions of years.

2.5 times that reconstructed for the ancestral condition of Rhynchosauria. The largest known rhynchosaur is a referred specimen of $H y$. huxleyi, with a lower jaw length or $\sim 470 \mathrm{~mm}$ and an estimated skull length of $420 \mathrm{~mm}$ (ISI R4, Chatterjee, 1974). This species is from the Upper Triassic of India and represents one of the youngest and most derived rhynchosaurs (Figure 10B). Therefore, the optimization of skull length in the phylogenetic tree of rhynchosaurs could be considered consistent with one of the prerequisites of a Cope's rule scenario (i.e., overall increase of body size in the evolutionary history of a lineage; Cope, 1887), and the other prerequisite (i.e., active trend) should be tested with an evolutionary model fitting analysis.

Maximum-likelihood model fitting suggest that the evolution of body size in rhynchosaurs is better explained by a Brownian 
Motion model (BM) in the calibrations with the age means and lower bounds (i.e., BM explains more than $50 \%$ of the data; Figure 10C; Table 2). As a result, under this model the increase in body size in hyperodapedontines and stenaulorhynchines can be explained as a non-directional exploitation of morphospace from small-bodied ancestors with a lower size constraint (i.e., passive diffusion or the "Stanley effect"; Albert and Johnson, 2011; Zanno and Makovicky, 2013). The presence of some cases of size reduction with respect to the reconstructed ancestral body size (e.g., $R$. articeps, I. genovefae, Hy. gordoni) likely contributes to a better fitting of a non-directional model over an active directional trend. When the phylogeny was calibrated using upper age bounds, stasis explains more than $99 \%$ of the data and favors the absence of an evolutionary trend. As a result, under both of these alternative evolutionary models, the increases in body size in the evolutionary history of rhynchosaurs do not represent an active trend and, therefore, the hypothesis of Cope's rule is not supported (Cope's rule is the result of an active directional trend; Kingsolver and Pfennig, 2004; Hone and Benton, 2005).

It should be taken into account that the maximum recorded or estimated skull length of each species is used for the analyses and these values can be easily affected by sampling artifacts. Low sample sizes may be correlated with lower maximum body sizes and the failure to sample fully grown individuals would affect the results. Therefore, the lower sample sizes of early Middle Triassic rhynchosaurs in comparison with those of the late Middle and Late Triassic (e.g., from the Manda beds and the Ischigualasto, Santa María, and lower Maleri formations) may result in an artifactual pattern of increased body size in the stratigraphically youngest species. However, there is no single evidence of a largebodied rhynchosaur in Early Triassic or early Middle Triassic beds worldwide and several of these early rhynchosaur forms seem to be skeletally mature individuals (Benton, 1990). As a result, the data used here seems to not be strongly affected by a size sample bias, but an increased rhynchosaur sample and better chronostratigraphic resolution, especially in the late Middle Triassic-early Late Triassic time span, will be crucial to test in the future the ambiguities in the evolutionary model fittings by the different time calibrations and the general results of the analyses recovered here.

\section{Paleobiogeography}

The Dispersal-Extinction-Cladogenesis analysis reconstructed the origin of Rhynchosauria as most likely occurring in Western Gondwana (the area that is now South Africa; 61.7\%; Figure 11), in agreement with previous qualitative statements (Butler et al., 2015), with this reconstruction preferred over a widespread ancestral range that included the current regions of South Africa and Europe (38.3\%). Central Laurasia (the area that is now Europe) is reconstructed as the ancestral area of Rhynchosauridae (80.4\%) and this ancestral range is retained in the four successive nodes that lead to Hyperodapedontinae $(83.2,100,100$, and 95.8\%). As a result, if Western Gondwana is interpreted as the ancestral area of the whole group, at least one dispersal event from this area to Central Laurasia must have occurred in the Induan-late Anisian. The ancestral area reconstruction of the node that includes stenaulorhynchines does not favor strongly any particular distribution, but the most likely are the ranges that include the current regions of South America and Tanzania-India-Madagascar (39.8\%), Europe and Tanzania-India-Madagascar (19.9\%) and South America and Europe (19.9\%). The reconstructions of the stenaulorhynchine node imply an expansion of the range of rhynchosaurs into South America and Tanzania-India-Madagascar and, if the most likely ancestral reconstruction is considered, a vicariant event between South America and Tanzania-India-Madagascar during the Anisian. The base of Hyperodapedontinae possesses several poorly supported ancestral area reconstructions, but the area that is now Europe is included in the ancestral range in $77.2 \%$ of them. The current regions of South America and Tanzania-India-Madagascar are included in 28.3 and $22.8 \%$ of the reconstructions, respectively. Therefore, the most likely reconstructions imply a range expansion into South America and/or Tanzania-India-Madagascar during the late Anisian-early Carnian time span. The reconstructions of the successively more deeply nested nodes of the Teyumbaita + Hyperodapedon clade include an ancestral range of Europe and South America as the most likely hypotheses (47.5-63.0\%). However, paleobiogeographic events within this clade are not discussed here because several species of the genus Hyperodapedon were not included in the analysis, including species collected in North America, India, and Africa.

In conclusion, the ancestral area reconstructions of the evolutionary history of rhynchosaurs imply dispersal events between broadly paleolatitudinally separated geographic areas (e.g., current regions of Europe, South America, and TanzaniaIndia-Madagascar). We note that ancestral area reconstructions such as these can be severely affected by incomplete sampling and missing data, and these results may change as additional rhynchosaur taxa are discovered and described, and as taxa such as Ammorhynchus and Mesodapedon are incorporated into phylogenetic analyses. However, as currently reconstructed, these biogeographic events imply that barriers to dispersal of rhynchosaurs across the paleo-Equator were either absent or present but at least temporarily permeable. This result is in agreement with the proposed cosmopolitan distribution of tetrapod species during the Middle Triassic, occurring in an interval when all the main landmasses were part of the supercontinent of Pangea (Shubin and Sues, 1991; Ezcurra, 2010). The paleobiogeographic history of hyperodapedontines goes beyond the scope of this paper, but its future study may shed light on the tempo and mode of the establishment of a different, more provincialized biogeographic scenario that has been proposed for the Late Triassic (Ezcurra, 2010; Whiteside et al., 2011).

\section{ACKNOWLEDGMENTS}

$\mathrm{RB}$ and ME were supported by an Emmy Noether Programme Award from the Deutsche Forschungsgemeinschaft (BU 2587/31 to $\mathrm{RB}$ ) and a Marie Curie Career Integration Grant (PCIG14-GA-2013-630123 ARCHOSAUR RISE to RB). FCM's participation in this project was partially supported by the 
Brazil Visiting Fellows scheme of the University of Birmingham. We thank the following curators, collection managers and researchers who provided access to specimens in their care: Billy de Klerk (AM), D. Hone (BRSUG), H. Morgenroth and R. Taylor (EXEMS), A. M. Ribeiro and J. Ferigolo (FZB), Márton Rabi and Davit Vasilyan (GPIT), S. Bandyopadhyay, and D. Sengupta (ISI), A. Kramarz (MACN-Pv), S. Chapman (NHMUK PV), R. Martínez (PVSJ), S. Kaal and R. Smith (SAM), D. Lockett (SHYMS), C. L. Schultz (UFRGS), and J. Radley (WARMS).

\section{REFERENCES}

Abdala, F., and Ribeiro, A. M. (2010). Distribution and diversity patterns of Triassic cynodonts (Therapsida, Cynodontia) in Gondwana. Palaeogeol. Palaeoclimatol. Palaeoecol. 286, 202-217. doi: 10.1016/j.palaeo.2010.01.011

Albert, J. S., and Johnson, D. M. (2011). Diversity and evolution of body size in fishes. Evol. Biol. 39, 324-340. doi: 10.1007/s11692-011-9149-0

Alroy, J. (2013). Online Paleogeographic Map Generator. Available online at: http:// fossilworks.org/?a=mapForm

Arratia, G. (2001). The sister-group of Teleostei: consensus and disagreements. J. Vert. Paleontol. 21, 767-773. doi: 10.1671/02724634(2001)021[0767:tsgotc]2.0.co;2

Benton, M. J. (1988). "The phylogeny of rhynchosaurs Reptilia, Diapsida), and two new species," in Fourth Symposium on Mesozoic Terrestrial Ecosystems, Short Papers, eds P. M. Currie and E. H. Coster (Drumheller, AB: Royal Tyrrell Museum of Palaeontology, Occasional Papers of the Tyrrell Museum of Palaeontology 3), 2-17.

Benton, M. J., Cook, E., and Turner, P. (2002). Permian and Triassic Red Beds and the Penarth Group of Great Britain. Peterborough: Joint Nature Conservation Committee.

Benton, M. J., Hart, M. B., and Clarey, T., (1993). A new rhynchosaur from the middle Triassic of Devon. Proc. Ussher Soci. 8, 167-171.

Benton, M. J., and Newell, A. J. (2014). Impacts of global warming on Permo-Triassic terrestrial ecosystems. Gond. Res. 25, 1308-1337. doi: 10.1016/j.gr.2012.12.010

Benton, M. J., and Spencer, P. S. (1995). Fossil Reptiles of Great Britain. London: Chapman and Hall.

Benton, M. J., and Twitchett, R. J. (2003). How to kill (almost) all life: the end-Permian extinction event. TREE 18, 358-365. doi: 10.1016/s01695347(03)00093-4

Benton, M. J., and Walker, A. D. (1996). Rhombopholis, a prolacertiform reptile from the Middle Triassic of England. Palaeontology 39, 763-782.

Benton, M. J., Warrington, G., Newell, A. J., and Spencer, P. S. (1994). "A review of the British middle triassic tetrapod assemblages," in In the Shadow of the Dinosaurs, eds N. C. Fraser and H.-D. Sues (Cambridge: Cambridge University Press), 131-160.

Benton, M. J. (1983a). Dinosaur success in the Triassic: a noncompetitive ecological model. Quart. Rev. Biol. 58, 29-55.

Benton, M. J. (1983b). The Triassic reptile Hyperodapedon from Elgin: functional morphology and relationships. Philos. Trans. R. Soc. Lond. B 302, 605-717.

Benton, M. J. (1984). Tooth form, growth, and function in Triassic rhynchosaurs (Reptilia, Diapsida). Palaeontology 27, 737-776.

Benton, M. J. (1985). Classification and phylogeny of the diapsid reptiles. Zool. J. Linn. Soc. 84, 97-164.

Benton, M. J. (1990). The species of Rhynchosaurus, a rhynchosaur (Reptilia, Diapsida) from the Middle Triassic of England. Philos. Trans. R. Soc. Lond. B $328,213-306$.

Benton, M. J. (2011). Archosaur remains from the Otter Sandstone Formation (Middle Triassic, late Anisian) of Devon, southern UK. Proc. Geol. Ass. 122, 25-33. doi: 10.1016/j.pgeola.2010.08.004

Bonaparte, J. F., Martinelli, A. G., Schultz, C. L., and Rubert, R. (2003). The sister group of mammals: small cynodonts from the Late Triassic of southern Brazil. Rev. Bras. Paleontol. 5, 5-27.

Bonaparte, J. F. (1982). Faunal replacement in the Triassic of South America. J. Vert. Paleontol. 2, 362-371.
We thank the editor M. Laurin and three anonymous reviewers for their comments, which improved the overall quality of the manuscript.

\section{SUPPLEMENTARY MATERIAL}

The Supplementary Material for this article can be found online at: http://journal.frontiersin.org/article/10.3389/fevo. 2015.00142

Broom, R. (1905). Preliminary notice of some new fossil reptiles collected by $\mathrm{Mr}$ Alfred Brown at Aliwal North, S. Africa. Rec. Alb. Mus. 1, 269-271.

Broom, R. (1906). On the South African diaptosaurian reptile Howesia. Proc. Zool. Soc. Lond. 1906, 591-600.

Broom, R. (1913). Note on Mesosuchus browni, Watson, and on a new South AfricanTriassic pseudosuchian (Euparkeria capensis). Rec. Alb. Mus. 2, 394-396.

Broom, R. (1925). On the South AfricanTriassic rhynchocephaloid reptile, 'Eosuchus' colletti, Watson. Rec. Alb. Mus. 3, 300-306.

Brusatte, S. L., Benton, M. J., Ruta, M., and Lloyd, G. T. (2008). Superiority, competition, and opportunism in the evolutionary radiation of dinosaurs. Science 321, 1485-1488. doi: 10.1126/science.1161833

Butler, M. A., and King, A. A. (2004). Phylogenetic comparative analysis: a modeling approach for adaptive evolution. Am. Nat. 164, 683-695. doi: $10.1086 / 426002$

Butler, R. J., Ezcurra, M. D., Montefeltro, F. C., Samanthi, A., and Sobral, G. (2015). A new species of basal rhynchosaur (Diapsida: Archosauromorpha) from the early Middle Triassic of South Africa, and the early evolution of Rhynchosauria. Zool. J. Linn. Soc. 174, 571-588. doi: 10.1111/zoj.12246

Carroll, R. L. (1976). Noteosuchus - the oldest know rhynchosaur. Ann. South Afr. Mus. 72, 37-57.

Chatterjee, S. (1969). Rhynchosaurs in time and space. Proc. Geol. Soc. Lond. 1958, 203-208.

Chatterjee, S. (1974). A rhynchosaur from the Upper Triassic Maleri Formation of India. Philos. Trans. R. Soc. Lond. B 267, 209-261.

Chatterjee, S. (1980). The evolution of rhynchosaurs. Mém. Soc. Géol. France N. Sér. 139, 57-65.

Coddington, J. A., and Scharff, N. (1994). Problems with zero-length branches. Cladistics 10, 415-423.

Colbert, E. H. (1984). Mesozoic reptiles, India and Gondwanaland. Ind. J. Earth Sci. 11, 25-37.

Cope, E. D. (1887). The Origin of the Fittest. Essays on evolution. New York, NY: Appleton.

Desojo, J. B., Heckert, A. B., Martz, J. W., Parker, W. G., Schoch, R. R., Small, B. J., et al. (2013). "Aetosauria: a clade of armoured pseudosuchians from the Late Triassic continental beds," in Anatomy, Phylogeny and Palaeobiology of Early Archosaurs and their Kin, eds S. J. Nesbitt, J. B. Desojo, and R. B. Irmis (London: Geological Society, Special Publications 379), 203-239.

Dilkes, D. W. (1995). The rhynchosaur Howesia browni from the Lower Triassic of South Africa. Palaeontology 38, 665-685.

Dilkes, D. W. (1998). The Early Triassic rhynchosaur Mesosuchus browni and the interrelationships of basal archosauromorph reptiles. Philos. Trans. R. Soc. Lond. B 353, 501-541.

Erwin, D. H. (1994). The Permo-Triassic extinction. Nature 367, 231-236.

Evans, S. E. (2003). At the feet of the dinosaurs: the early history and radiation of lizards. Biol. Rev. 78, 513-551. doi: 10.1017/S14647931030 06134

Ezcurra, M. D., Martinelli, A. G., Fiorelli, L. E., Da-Rosa, A. A. S., and Desojo, J. B. (2015). Archosauromorph remains from the Tarjados Formation (Early-Middle Triassic, NW Argentina). Ameghiniana 52, 475-486. doi: 10.5710/AMGH.12.05.2015.2907

Ezcurra, M. D., Scheyer, T. M., and Butler, R. J. (2014). The origin and early evolution of Sauria: reassessing the Permian saurian fossil record and the timing of the crocodile-lizard divergence. PLoS ONE 9:e89165. doi: 10.1371/journal.pone.0089165 
Ezcurra, M. D. (2010). Biogeography of Triassic tetrapods: evidence for provincialism and driven sympatric cladogenesis in the early evolution of modern tetrapod lineages. Proc. R. Soc. B 277, 2547-2552. doi: 10.1098/rspb.2010.0508

Ezcurra, M. D. (2014). The osteology of the basal archosauromorph Tasmaniosaurus triassicus from the Lower Triassic of Tasmania, Australia. PLoS ONE 9:e86864. doi: 10.1371/journal.pone.0086864

Felsenstein, J. (1973). Maximum likelihood estimation of evolutionary trees from continuous characters. Am. J. Hum. Gen. 25, 471-492.

Fröbisch, J. (2013). Vertebrate diversity across the end-Permian extinctionseparating biological and geological signals. Palaeogeol. Palaeoclimatol. Palaeoecol. 372, 50-61. doi: 10.1016/j.palaeo.2012.10.036

Gaffney, E. S. (1986). "Triassic and early Jurassic turtles," in The Beginning of the Age of Dinosaurs: Faunal Changes Across the Triassic-Jurassic Boundary, ed K. Padian (Cambridge: Cambridge University Press), 183-187.

Gauthier, J. A., Kluge, A. G., and Rowe, T. (1988). Amniote phylogeny and the importance of fossils. Cladistics 4, 105-209.

Goloboff, P. A., Farris, J. S., Källersjö, M., Oxelman, B., Ramírez, M., and Szumik, C. A. (2003). Improvements to resampling measures of group support. Cladistics 19, 324-332. doi: 10.1111/j.1096-0031.2003.tb00376.x

Goloboff, P. A., Farris, J. S., and Nixon, K. C. (2008). TNT, a free program for phylogenetic analysis. Cladistics $24,774-786$. doi: 10.1111/j.10960031.2008.00217.x

Goloboff, P. A., Mattoni, C. I., and Quinteros, A. S. (2006). Continuous characters analyzed as such. Cladistics 22, 589-601. doi: 10.1111/j.1096-0031.2006.00122.x

Gow, C. E. (1975). The morphology and relationships of Youngina capensis Broom and Prolacerta broomi Parrington. Palaeontol. Afr. 18, 89-131.

Hancox, P. J., Shishkin, M. A., Rubidge, B. S., and Kitching, J. W. (1995). A threefold subdivision of the Cynognathus Assemblage Zone (Beaufort Group, South Africa) and its palaeogeographical implications. South Afr. J. Sci. 91, 143-144.

Hancox, P. J. (2000). The continental Triassic of South Africa. Zent. Geol. Paläontol. Teil I 1998, 1285-1324.

Harmon, L., Losos, J. B., Davies, T. J., Gillespie, R. G., Gittleman, J. L., Jennings, W. B., et al. (2010). Early bursts of body size and shape evolution are rare in comparative data. Evolution 64, 2385-2396. doi: 10.1111/j.15585646.2010.01025.x

Harmon, L. J., Melville, J., Larson, A., and Losos, J. B. (2008). The role of geography and ecological opportunity in the diversification of day geckos (Phelsuma). Syst. Biol. 57, 562-573. doi: 10.1080/10635150802304779

Haughton, S. H. (1924). On a new type of thecodont from the Middle Beaufort Beds. Ann. Trans. Mus. 11, 93-97.

Haughton, S. H. (1932). On a collection of Karoo vertebrates from Tanganyika Territory. Q. J. Geol. Soc. London 88, 634-668.

Hone, D. W. E., and Benton, M. J. (2005). The evolution of large size: how does Cope's rule work? TREE 20, 4-6. doi: 10.1016/j.tree.2004.10.012

Hone, D. W. E., and Benton, M. J. (2008). A new genus of rhynchosaur from the Middle Triassic of south-west England. Palaeontology 51, 95-115. doi: 10.1111/j.1475-4983.2007.00739.x

Huene, F., von. (1929). Über Rhynchosaurier und andere Reptilien aus den Gondwana-Ablagerungen Südamerikas. Geol. Paläontol. Abh. N. Folge 17, 1-62.

Huene, F., von. (1938). Stenaulorhynchus, ein Rhynchosauride der ostafrikanischer Obertrias. Nov. Acta Leopol. N. Folge 6, 83-121.

Huene, F., von. (1939). Die Verwandtschaftsgeschichte der Rhynchosauriden des Südamerikanischen Gondwanalandes. Physis 14, 499-523.

Huene, F., von. (1946). Die grossen Stämme der Tetrapoden in den geologischen Zeiten. Biol. Zent. 65, 268-275.

Huene, F., von. (1956). Paläontologie und Phylogenie der Niederen Tetrapoden. Jena: Fischer.

Hunt, G. (2006). Fitting and comparing models of phyletic evolution: random walks and beyond. Paleobiology 32, 578-601. doi: 10.1666/05070.1

Huxley, T. H. (1859). Postscript to: on the sandstones of Morayshire (Elgin \& c.) containing reptilian remains; and on their relations to the Old Red Sandstone of that county (by R. I. Murchison). Q. J. Geol. Soc. Lond. 15, 435-436.

Huxley, T. H. (1887). Further observations upon Hyperodapedon gordoni. Q. J. Geol. Soc. Lond. 43, 675-694.

Jaekel, O. (1904). Über ein neues Reptil aus dem Buntsandstein der Eifel. Zeit. Deut. Geol. Gesel. 56, 90-94.
Jones, M. E. H., Anderson, C. L., Hipsley, C. A., Müller, J., Evans, S. E., and Schoch, R. R. (2013). Integration of molecules and new fossils supports a Triassic origin for Lepidosauria (lizards, snakes, and tuatara). BMC Evol. Biol. 13:208. doi: 10.1186/1471-2148-13-208

Kingsolver, J. G., and Pfennig, D. W. (2004). Individual-level selection as a cause of Cope's rule of phyletic size increase. Evolution 58, 1608-1612. doi: 10.1111/j.0014-3820.2004.tb01740.x

Kuhn, O. (1969). "Proganosauria, Bolosauria, Placodontia, Araeoscelidia, Trilophosauria, Weigeltisauria, Millerosauria, Rhynchocephalia, Protorosauria," in Handbuch der Paläoherpetologie, Vol. 9, ed O. Kuhn (Stuttgart: Gustav Fischer), 1-74.

Langer, M. C., and Schultz, C. L. (2000). A new species of the Late Triassic rhynchosaur Hyperodapedon from the Santa Maria Formation of South Brazil. Palaeontology 43, 633-652. doi: 10.1111/1475-4983.00143

Langer, M. C. (2005). Studies on continental Late Triassic tetrapod biochronology. II. The Ischigualastian and a Carnian global correlation. J. South Am. Earth Sci. 19, 219-239. doi: 10.1016/j.jsames.2005.04.002

Langer, M. C., Boniface, M., Cuny, G., and Barbieri, L. (2000a). The phylogenetic position of Isalorhynchus genovefae, a Late Triassic rhynchosaur from Madagascar. Ann. Paléontol. 86, 101-127. doi: 10.1016/S0753-3969(00)80002-6

Langer, M. C., Ferigolo, J., and Schultz, C. L. (2000b). Heterochrony and tooth evolution in hyperodapedontine rhynchosaurs (Reptilia, Diapsida). Lethaia 33, 119-128. doi: 10.1080/00241160050150258

Langer, M. C., Montefeltro, F. C., Hone, D. W. E., Whatley, R., and Schultz, C. L. (2010). On Fodonyx spenceri and a new rhynchosaur from the Middle Triassic of Devon. J. Vert. Paleontol. 30, 1884-1888. doi: 10.1080/02724634.2010.521901

Laurin, M. (1991). The osteology of a lower permian eosuchian from Texas and a review of diapsid phylogeny. Zool. J. Linn. Soc. 101, 59-95. doi: 10.1111/j.10963642.1991.tb00886.x

Lautenschlager, S., and Desojo, J. B. (2011). reassessment of the middle triassic rauisuchian archosaurs Ticinosuchus ferox and Stagonosuchus nyassicus. Paläontol. Zeit. 85, 357-381. doi: 10.1007/s12542-011-0105-1

Liu, J., and Olsen, P. (2010). The phylogenetic relationships of Eucynodontia (Amniota: Synapsida). J. Mamm. Evol. 17, 151-176. doi: 10.1007/s10914-0109136-8

Lucas, S. G. (2010). "The Triassic timescale based on non-marine tetrapod biostratigraphy and biochronology," in The Triassic Timescale, ed S. G. Lucas (London: Special Publication Geological Society 334), 447-500.

Lucas, S. G., and Schoch, R. R. (2002). Triassic temnospondyl biostratigraphy, biochronology and correlation of the German Buntsandstein and North American Moenkopi Formation. Lethaia 35, 97-106. doi: $10.1080 / 002411602320183962$

Martínez, R. N., Sereno, P. C., Alcober, O. A., Colombi, C. E., Renne, P. R., Montañez, I. P., et al. (2011). A basal dinosaur from the dawn of the dinosaur era in southwestern Pangaea. Science 331, 206-210. doi: 10.1126/science. 1198467

Looy, C. V., Twitchett, R. J., Dilcher, D. L., Van Konijnenburg-Van Cittert, J. H. A., and Visscher, H. (2001). Life in the end-Permian dead zone. Proc. Nat. Acad. Sci. U.S.A. 98, 7879-7883. doi: 10.1073/pnas.131218098

Marjanovic, D., and Laurin, M. (2008). Assessing confidence intervals for stratigraphic ranges of higher taxa: the case of Lissamphibia. Acta Palaeontol. Pol. 53, 413-432. doi: 10.4202/app.2008.0305

Montefeltro, F. C., Langer, M. C., and Schultz, C. L. (2010). Cranial anatomy of a new genus of hyperodapedontine rhynchosaur (Diapsida, Archosauromorpha) from the Upper Triassic of Southern Brazil. Earth Env. Sci. Trans. R. Soc. Edinburgh 101, 27-52. doi: 10.1017/S1755691010009060

Montefeltro, F. C., Bittencourt, J. S., Langer, M. C., and Schultz, C. L. (2013). Postcranial anatomy of the hyperodapedontine rhynchosaur Teyumbaita sulcognathus (Azevedo and Schultz, 1987) from the Late Triassic of southern Brazil. J. Vert. Paleontol. 33, 67-84. doi: 10.1080/02724634.2012.710285

Mukherjee, D., and Ray, S. (2014). A new Hyperodapedon (Archosauromorpha, Rhynchosauria) from the Upper Triassic of India: implications for rhynchosaur phylogeny. Palaeontology 57, 1241-1276. doi: 10.1111/pala.12113

Nesbitt, S. J. (2011). The early evolution of archosaurs: relationships and the origin of major clades. Bull. Am. Mus. Nat. Hist. 352, 1-292. doi: 10.1206/352.1

Nesbitt, S., and Whatley, R. (2004). The first discovery of a rhynchosaur from the Upper Moenkopi Formation (Middle Triassic) of northern Arizona. PaleoBios $24,1-10$. 
Nesbitt, S. J., Sidor, C. A., Irmis, R. B., Angielczyk, K. D., Smith, R. M. H., and Tsuji, L. A. (2010). Ecologically distinct dinosaurian sister-group shows early diversification of Ornithodira. Nature 464, 95-98. doi: 10.1038/nature08718

Nopsca, F. (1928). The genera of reptiles. Palaeobiology 1, 163-188.

Osborn, H. F. (1903). The reptilian subclasses Diapsida and Synapsida and the early history of the Diaptosauria. Mem. Am. Mus. Nat. Hist. 1, 449-507.

Owen, R. (1842a). Description of an extinct lacertian, Rhynchosaurus articeps, Owen, of which the bones and foot-prints characterize the upper New Red Sandstone at Grinshill, near Shrewsbury. Trans. Camb. Phil. Soc. 7, 355-369.

Owen, R. (1842b). Description of parts of the skeleton and teeth of five species of the genus Labyrinthodon (Lab. leptognathus, Lab. pachygnathus, and Lab. ventricosus, from the Coton-end and Cubbington Quarries of the Lower Warwick Sandstone; Lab. Jaegeri, from Guy's Cliff, Warwick; and Lab. scutulatus, from Leamington); with remarks on the probable identity of the Cheirotherium with this genus of extinct batrachians. Trans. Geol. Soc. Lond. 6, 515-543. doi: 10.1144/transgslb.6.2.515

Pagel, M. (1999). Inferring the historical patterns of biological evolution. Nature 401, 877-884. doi: 10.1038/44766

Pritchard, A. C., Turner, A. H., Nesbitt, S. J., Irmis, R. B., and Smith, N. D. (2015). Late Triassic tanystropheids (Reptilia, Archosauromorpha) from northern New Mexico (Petrified Forest Member, Chinle Formation) and the biogeography, functional morphology, and evolution of Tanystropheidae. J. Vert. Paleontol. 35:e911186. doi: 10.1080/02724634.2014.911186

R. Development Core Team (2013). R: A Language and Environment for Statistical Computing. Vienna: R Foundation for Statistical Computing. Available online at http://www.R-project.org/

Raup, D. M., and Sepkoski, J. J. Jr. (1982). Mass extinctions in the marine fossil record. Science 215, 1501-1503. doi: 10.1126/science.215.4539.1501

Ree, R. H., and Smith, S. A. (2008). Maximum likelihood inference of geographic range evolution by dispersal, local extinction, and cladogenesis. Syst. Biol. 57, 4-14. doi: 10.1080/10635150701883881

Ree, R. H., Moore, B. R., Webb, C. O., and Donoghue, M. J. (2005). A likelihood framework for inferring the evolution of geographic range on phylogenetic trees. Evolution 59, 2299-2311. doi: 10.1111/j.0014-3820.2005.tb00940.x

Romer, A. S. (1956). Osteology of the Reptiles. Chicago: University of Chicago Press.

Romer, A. S. (1963). La evolución explosiva de los rhynchosaurios del Triásico. Rev. Mus. Arg. Cien. Nat. Ber. Riv. Ins. Nac. Inv. Cien. Nat. (Cien. Zool.) 8, 1-14.

Romer, A. S. (1966). Vertebrate Paleontology, 3rd Edn. Chicago: University of Chicago Press.

Rubidge, B. S. (2005). Re-uniting lost continents - fossil reptiles from the ancient Karoo and their wanderlust. South Afr. J. Geol. 108, 135-172. doi: 10.2113/108.1.135

Sales, M. A. F., and Schultz, C. L. (2014). Paleoneurology of Teyumbaita sulcognathus (Diapsida: Archosauromorpha) and the sense of smell in rhynchosaurs. Palaeontol. Electr. 17, 10.

Schoch, R. R., and Sues, H.-D. (2015). A Middle Triassic stem-turtle and the evolution of the turtle body plan. Nature 523, 584-587. doi: $10.1038 /$ nature 14472

Scotese, C. R. (2001). Atlas of Earth History, Vol. 1, Paleogeography. Arlington, TX: PALEOMAP Project.

Shubin, N. H., and Sues, D. (1991). Biogeography of early Mesozoic continental tetrapods: patterns and implications. Paleobiology 17, 214-230.
Smith, R. M. H., and Botha-Brink, J. (2014). Anatomy of a mass extinction: sedimentological and taphonomic evidence for drought-induced die-offs at the Permo-Triassic boundary in the main Karoo Basin, South Africa. Palaeogeol. Palaeoclimatol. Palaeoecol. 396, 99-118. doi: 10.1016/j.palaeo.2014.01.002

Spielmann, J. A., Lucas, S. G., Rinehart, L. F., and Heckert, A. B. (2008). The Late Triassic archosauromorph Trilophosaurus. Bull. N. Mex. Mus. Nat. Hist. Sci. 43, $1-177$.

Stocker, M. R., and Butler, R. J. (2013). "Phytosauria," in Anatomy, Phylogeny and Palaeobiology of Early Archosaurs and their Kin, eds S. J. Nesbitt, J. B. Desojo, and R. B. Irmis (London: Geological Society, Special Publication 379), 91-117.

Sues, H.-D., and Fraser, N. C. (2013). Triassic Life on Land: The Great Transition. New York, NY: Columbia University Press.

Sues, H.-D., Desojo, J. B., and Ezcurra, M. D. (2013). "Doswelliidae: a clade of unusual armoured archosauriforms from the Middle and Late Triassic," in Anatomy, Phylogeny and Palaeobiology of Early Archosaurs and their Kin, eds S. J. Nesbitt, J. B. Desojo, and R. B. Irmis (London: Geological Society, Special Publication 379), 49-58.

Swofford, D. L. (1998). PAUP*. Phylogenetic Analysis Using Parsimony ( ${ }^{*}$ and Other Methods). Version 4. Sunderland, Massachusetts: Sinauer Associates.

Watson, D. M. S. (1912). Eosuchus colletti, gen. et spec. nov. Rec. Alb. Mus. 2, 298-299.

Watson, D. M. S. (1917). A sketch classification of the Pre-Jurassic tetrapod vertebrates. Proc. Zool. Soc. Lond. 1917, 167-186.

Whatley, R. (2005). Phylogenetic Relationship of Isalorhynchus genovefae, the Rhynchosaur (Reptilia, Archosauromorpha) from Madagascar. Santa Barbara: Ph.D. dissertation, University of California.

Whiteside, J. H., Grogan, D. S., Olsen, P. E., and Kent, D. V. (2011). Climatically driven biogeographic provinces of Late Triassic tropical Pangea. Proc. Nat. Acad. Sci. U.S.A. 108, 8972-8977. doi: 10.1073/pnas.1102 473108

Wilkinson, M., and Benton, M. J. (1995). Missing data and rhynchosaur phylogeny. Hist. Biol. 10, 137-150. doi: 10.1080/10292389509380517

Woodward, A. S. (1907). On Rhynchosaurus articeps (Owen). Report of the British Ass. Adv. Sci. 1907, 293-299.

Yu, Y., Harris, A. J., Blair, C., and He, X. J. (2015). RASP (Reconstruct Ancestral State in Phylogenies): a tool for historical biogeography. Mol. Phyl. Evol. 87, 46-49. doi: 10.1016/j.ympev.2015.03.008

Zanno, L. E., and Makovicky, P. J. (2013). No evidence for directional evolution of body mass in herbivorous theropod dinosaurs. Proc. R. Soc. B 280, 20122526. doi: $10.1098 / \mathrm{rspb} .2012 .2526$

Conflict of Interest Statement: The authors declare that the research was conducted in the absence of any commercial or financial relationships that could be construed as a potential conflict of interest.

Copyright (c) 2016 Ezcurra, Montefeltro and Butler. This is an open-access article distributed under the terms of the Creative Commons Attribution License (CC BY). The use, distribution or reproduction in other forums is permitted, provided the original author(s) or licensor are credited and that the original publication in this journal is cited, in accordance with accepted academic practice. No use, distribution or reproduction is permitted which does not comply with these terms. 